Review

\title{
Aquatic Environment Exposure and Toxicity of Engineered Nanomaterials Released from Nano-Enabled Products: Current Status and Data Needs
}

\author{
Mbuyiselwa Shadrack Moloi ${ }^{1}{ }^{(}$, Raisibe Florence Lehutso $^{2}{ }^{\circledR}$, Mariana $\left._{\text {Erasmus }}{ }^{3}{ }^{(}\right)$, Paul Johan Oberholster $^{1}$ \\ and Melusi Thwala 1,2,*(D) \\ 1 Centre for Environmental Management, University of the Free State, Bloemfontein 9031, South Africa; \\ 2012164071@ufs4life.ac.za (M.S.M.); OberholsterPJ@ufs.ac.za (P.J.O.) \\ 2 Water Centre, Council for Scientific and Industrial Research, Pretoria 0001, South Africa; flehutso@csir.co.za \\ 3 Centre for Mineral Biogeochemistry, University of the Free State, Bloemfontein 9031, South Africa; \\ ErasM@ufs.ac.za \\ * Correspondence: mthwala@csir.co.za
}

check for updates

Citation: Moloi, M.S.; Lehutso, R.F.; Erasmus, M.; Oberholster, P.J.; Thwala, M. Aquatic Environment Exposure and Toxicity of Engineered Nanomaterials Released from Nano-Enabled Products: Current Status and Data Needs. Nanomaterials 2021, 11, 2868. https://doi.org/ $10.3390 /$ nano11112868

Academic Editors: Ilaria Corsi and Julian Blasco

Received: 27 September 2021

Accepted: 23 October 2021

Published: 27 October 2021

Publisher's Note: MDPI stays neutral with regard to jurisdictional claims in published maps and institutional affiliations.

Copyright: (C) 2021 by the authors Licensee MDPI, Basel, Switzerland. This article is an open access article distributed under the terms and conditions of the Creative Commons Attribution (CC BY) license (https:// creativecommons.org/licenses/by/ $4.0 /)$.

\begin{abstract}
Rapid commercialisation of nano-enabled products (NEPs) elevates the potential environmental release of engineered nanomaterials (ENMs) along the product life cycle. The current review examined the state of the art literature on aquatic environment exposure and ecotoxicity of product released (PR) engineered nanomaterials (PR-ENMs). Additionally, the data obtained were applied to estimate the risk posed by PR-ENMs to various trophic levels of aquatic biota as a means of identifying priority NEPs cases that may require attention with regards to examining environmental implications. Overall, the PR-ENMs are predominantly associated with the matrix of the respective NEPs, a factor that often hinders proper isolation of nano-driven toxicity effects. Nevertheless, some studies have attributed the toxicity basis of observed adverse effects to a combination of the released ions, ENMs and other components of NEPs. Notwithstanding the limitation of current ecotoxicology data limitations, the risk estimated herein points to an elevated risk towards fish arising from fabrics' PR-nAg, and the considerable potential effects from sunscreens' PR-nZnO and PR-nTiO 2 to algae, echinoderms, and crustaceans ( $\mathrm{PR}-\mathrm{nZnO}$ ), whereas $\mathrm{PR}-\mathrm{nTiO} \mathrm{O}_{2}$ poses no significant risk to echinoderms. Considering that the current data limitations will not be overcome immediately, we recommend the careful application of similar risk estimation to isolate/prioritise cases of NEPs for detailed characterisation of ENMs' release and effects in aquatic environments.
\end{abstract}

Keywords: product released nanomaterials; nano-enabled product; risk assessment; ecotoxicology of PR-ENMs

\section{Introduction}

The advancement of nanotechnology has increased the frequency of engineered nanomaterials' (ENMs) incorporation into products in pursuit of their superior properties to enhance product formulations. For instance, ENMs are favoured because they exhibit relatively increased surface area and pore volume [1], which facilitates enhanced adsorption, ion exchange and increased reactivity [1,2]. Product formulations containing ENMs are called nano-enabled products (NEPs), and their global market is rapidly increasing being forecast to be worth USD 125 billion in 2024, from $c a$ USD 32.9 billion in 2016 [3]. The number of NEPs listed in various global inventories has also increased year on year, from 54 in 2005 [4] to above 5000 in 2020 [5]. In approximately over a decade, nanotechnology has advanced from the research and development phase to daily use in products [5].

The global NEPs' markets are currently dominated by health and fitness products, mainly active wear, sunscreens, cosmetics and sporting goods [4,6-8]. In health and fitness products, the ENMs are predominantly surface-bound or suspended in liquid; a 
character that increases their potential release into water environments (medium to high environmental exposure potential) $[6,7,9,10]$.

The ENMs in NEPs are commonly not permanently fixed in the product matrix and can be released into the environment during product use and the end of life stages. The emission of ENMs from NEPs into the environment, nanopollution, is expected to be proportional to the rising commercialisation of NEPs. The ENMs released from NEPs are referred to as product released (PR) engineered nanomaterials (PR-ENMs) to distinguish them from pristine counterparts (bare or not incorporated in products).

Data on the environmental risks associated with PR-ENMs are limited as their hazard, exposure dynamics and toxicity effects are not well characterised [7,9-12]. Partly, this can be attributed to the limited suitability of current analytical techniques to examine ENMs in complex media as well as the fairly recent emergence of the focus on examining ENMs' environmental risks arising from NEPs. For instance, the NEP inventory focusing on establishing NEPs' market penetration was initiated in 2005 [4], while those with an interest on ENMs' environmental exposure potential were only introduced in 2012 [6], 2015 [8] and 2019 [7], respectively, from Europe, Singapore and South Africa. Similarly, studies that experimentally investigated the environmental exposure potential from NEPs such as paints, sunscreens and textiles emerged around 2008-2010 [13-15]. While challenges concerning risk determination approaches currently persist, various guides have been developed pertaining to ENMs' characterisation requirements and strategies to mitigate potential risks, for instance, by the Food and Drug Administration (FDA) in the USA [16,17], European Commission [18] and the Organisation for Economic Development and Cooperation (OECD) [19].

The examination of PR-ENMs' environmental exposure and effects are hindered predominantly by the low concentrations (ranging in the lower ppb) that are released into the environment, thus limiting analytical characterisation (exposure) and hazard assessment $[9,20]$. For instance, as little as 0.007 to $0.5 \%$ of PR-ENMs (nAg and nTiO ${ }_{2}$ ) was released from textile and paint products' NEPs [20,21]. From sunscreens, 0.16-1.16 $\mu \mathrm{g} / \mathrm{L}$ $\mathrm{nTiO}_{2}$ was released into water environments [22]. Overall, the low release amounts and limited suitability of current analytical tools for "nano" characterisation in complex media have been raised as priority challenges [10,23-25] and various detailed reviews have focused on this matter [26-31].

Concerning the exposure of aquatic systems, wastewater treatment plants (WWTPs) have been identified as sinks and secondary sources of ENMs into water resources (Figure 1) and, thus, should be considered in PR-ENMs' environmental exposure and risk assessment. For instance, $\mathrm{nZnO}$ and $\mathrm{nTiO}_{2}$ concentrations in WWTPs have been correlated with the usage of NEPs [32]. Considerable amounts of the PR-ENMs can be retained in sludge, for instance, with a sorption density of $3.49 \mathrm{~g} / \mathrm{kg}$ mixed liquid suspended solid (MLSS) for $\mathrm{nZnO}$ and $4.67 \mathrm{~g} / \mathrm{kg}$ MLSS for $\mathrm{nTiO}_{2}$ [33], while sludge application as a fertiliser in agricultural fields can emit PR-ENMs into aquatic bodies during runoff events [34].

The current paper reviews the state of the art literature concerning the characterisation of release and toxicity effects of PR-ENMs in aquatic ecosystems and their respective risk to guide the identification of product emissions that could pose notable unwanted consequences. Specifically, the risk estimation was meant to direct research and regulation attention to products that need prioritization for ENMs' aquatic exposure and hazard characterisation. The review identifies key gaps and outlines priority research needs on the environmental exposure and hazardous effects of PR-ENMs in water systems. Specific to the release and toxicity of PR-ENMs in real aquatic environments, only a few studies exist [35-37]. The current review is the first to consolidate the release and effects data for risk estimation as the handful of previous reviews have mainly presented the data on PR-ENMs [12,20,27,38-45]. 


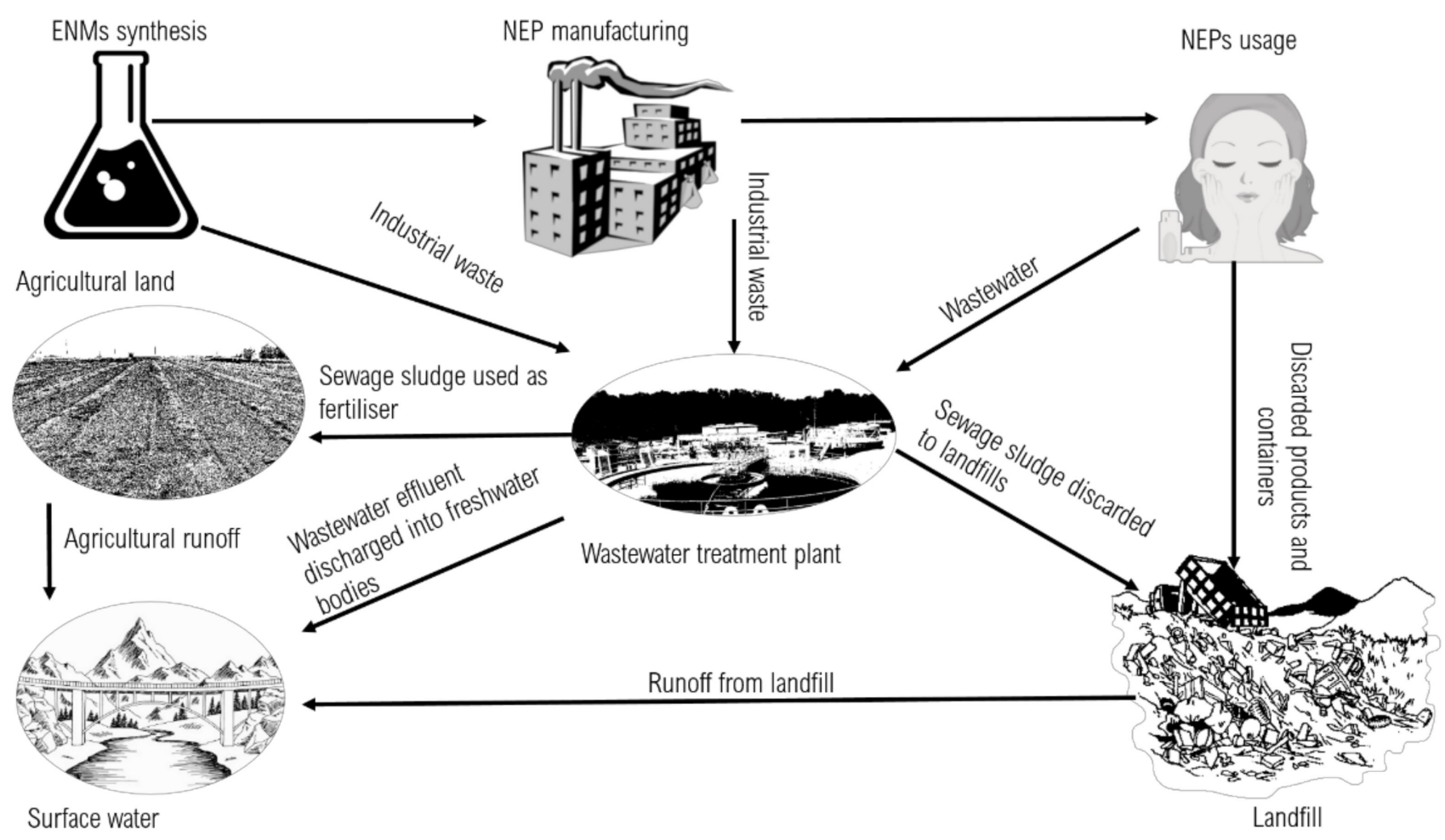

Figure 1. PR-ENMs pathway in the environment. The ENMs are depicted from manufacturing to different environmental exposure pathways in the environment.

The data reviewed herein were obtained from peer-reviewed articles in Google Scholar and Science Direct databases. Articles were limited to the 2008-2021 period and filtered using the following keywords: product released nanomaterials, nano-enabled products, engineered nanomaterial released from products and toxicity effects of engineered nanomaterial released from nano-enabled products. A total of 322 peer-reviewed articles were obtained at the first tier, but 181 were discarded from further analysis as they did not fit the scope of this review; thus, 142 articled were reviewed.

\section{ENMs Identified to Be Commonly Used in NEPs That Exhibit Medium to High Environmental Exposure Potential}

Generally, ENMs are incorporated in NEPs to enhance specific product properties based on the character of the ENMs being applied [46-49]. This section reviews the beneficial properties of ENMs (titanium dioxide $\left(\mathrm{nTiO}_{2}\right)$, zinc oxide nanoparticles $(\mathrm{nZnO})$, silicon dioxide nanoparticles $\left(\mathrm{nSiO}_{2}\right)$ and silver $(\mathrm{nAg})$ that make them attractive for incorporation in NEPs. The ENMs' sample was selected because of the high production rates (Table 1), wide distribution across product categories and high usage in NEPs.

Table 1. The global production and application of selected engineered nanomaterials (ENMs) based on beneficial properties.

\begin{tabular}{ccc}
\hline ENMs Type & Global Production (Tons/Year) & References \\
\hline $\mathrm{nTiO}_{2}$ & $10,000-15,000$ & {$[50,51]$} \\
$\mathrm{nZnO}$ & $1000-36,000$ & {$[39,51]$} \\
$\mathrm{nAg}$ & 420 & {$[51]$} \\
$\mathrm{nSiO}_{2}$ & $1,400,000$ & {$[51]$} \\
\hline
\end{tabular}

Twenty-five percent (25\%) of all NEPs in the consumer market are reported to be incorporated with $\mathrm{nAg}, \mathrm{nTiO}_{2}$ or $\mathrm{nSiO}_{2}$ in [52]. Moeta et al. [7] and Zhang et al. [8] also reported that from the 264 and 1432 NEPs surveyed, respectively, $\mathrm{nTiO}_{2}, \mathrm{nSiO}_{2}, \mathrm{nAg}$ 
and $\mathrm{nZnO}$ were the most common ENMs in products found in South Africa $(74 \%)$ and Singapore $(>80 \%)$. Similarly, these ENMs were found in most of the NEPs found in Europe (Figure 2). In all inventories $[4,7,8,53,54]$, these ENMs were predominant in NEPs categorised as having medium to high environmental release potential, suggesting that they were likely to be emitted to the environment with relative ease.

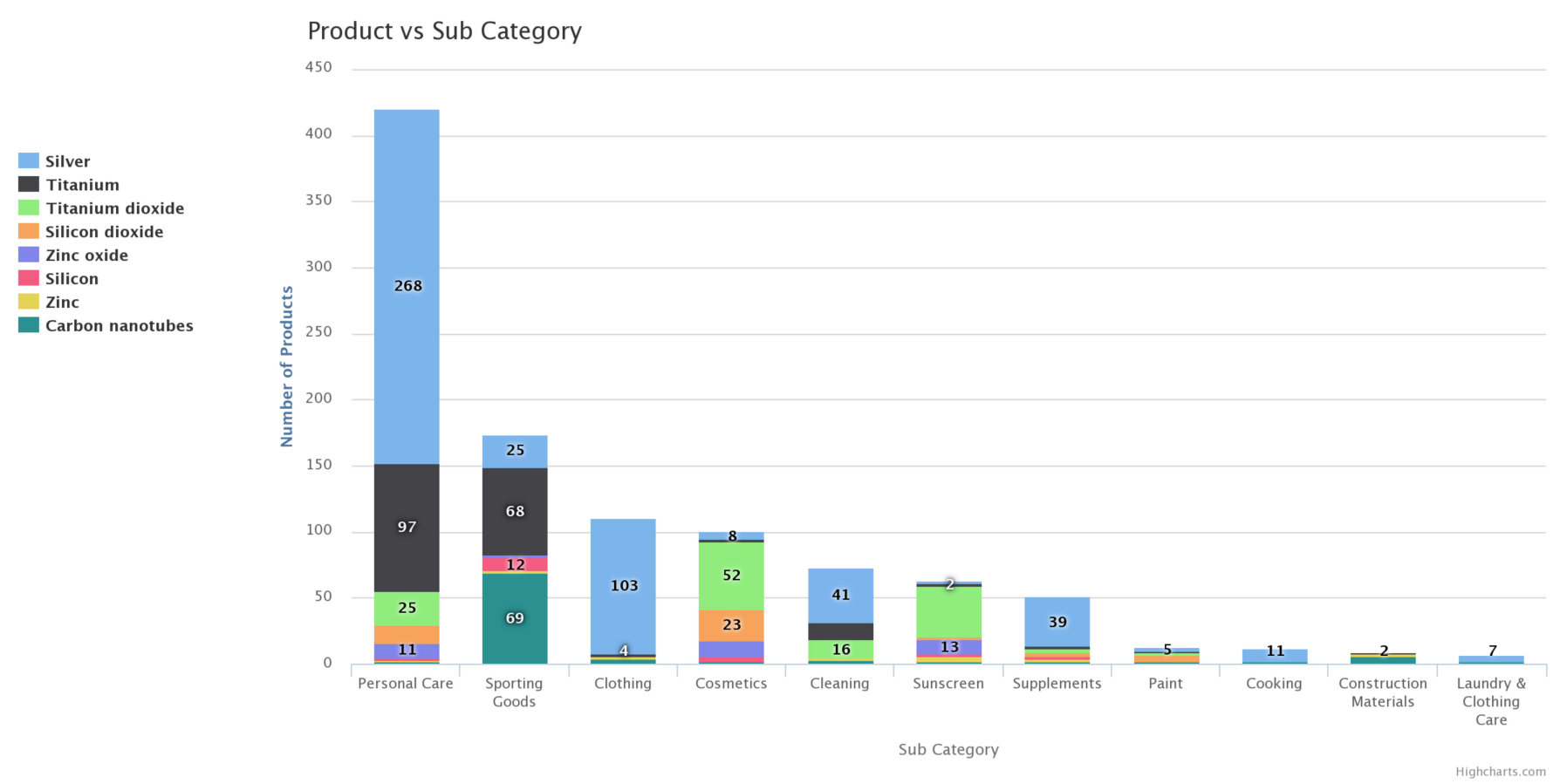

Figure 2. The incorporation of $\mathrm{nAg}, \mathrm{nTiO}_{2}, \mathrm{nZnO}$ and $\mathrm{nSiO}_{2}$ in various nano-enabled products' (NEPs) categories [53].

\subsection{Titanium Dioxide Nanoparticles $\left(n \mathrm{TiO}_{2}\right)$}

$\mathrm{nTiO}_{2}$ is one of the most highly produced ENMs globally (Table 1 ) as a white pigment applied in many NEPs [47]. Additionally, $\mathrm{nTiO}_{2}$ is favoured for its brightness, resistance to discolouration, high refractive index and broad ultraviolet (UV) spectrum that allows for maximum blockage and protection from $\mathrm{UV}$ radiation $[55,56]$. $\mathrm{nTiO}_{2}$ is used in pharmaceuticals as photosensitisers in photodynamic therapy [57], in cosmetics as sun filters in day creams and foundations [58], and in toothpaste as a white pigment [59,60]. The high usage of $\mathrm{nTiO}_{2}$ in cosmetics and fabrics for its UV filtration [55,56,61], high refractive index and as a colouring agent in paints [62,63], as well as its self-cleaning property in textiles and paints $[62,64]$ has led to the continuously rising production over the years.

$\mathrm{nTiO}_{2}$ is produced in three crystalline forms: anatase, rutile and brookite; the former two are the most commonly found in products [59,65]. Anatase and rutile are predominantly used in NEPs due to their high energy absorbing properties [66,67]. Rutile is a more stable form of $\mathrm{nTiO}_{2}$, while anatase is metastable and transforms into the rutile phase at elevated temperatures [68]. From a sample of six sunscreens, rutile $\mathrm{nTiO}_{2}$ was present in three sunscreens, while the combination of rutile and anatase forms of $\mathrm{nTiO}_{2}$ was in one sunscreen $[10,22,69]$. Overall, most studies demonstrate that rutile $\mathrm{nTiO}_{2}$ is the most widely used form [10,58,59,70-73]. Rutile $\mathrm{nTiO}_{2}$ has also been reported in paints [10] and cotton fabrics [61]. Although both anatase and rutile $\mathrm{nTiO}_{2}$ are widely applied in products, rutile appears to be the most preferred derivative, probably due to its relatively superior UV absorbance, lower photoreactivity and higher photocatalysis than anatase $[61,72,74]$.

In addition to the form of $\mathrm{nTiO}_{2}$, its size, shape and surface coating characteristics have also been reported. Bairi et al. [72] and Lu et al. [69] have confirmed smaller than $100 \mathrm{~nm} \mathrm{nTiO} 2$ in products. In sunscreens, $\mathrm{nTiO}_{2}$ has also been reported to be in the size range of 8-34 nm (irregularly/angularly shaped) [7,10,75-78] and 44.4-96.3 nm (needle shaped) $[10,22,79-82]$. 
In cotton fabrics, the size of $\mathrm{nTiO}_{2}$ has been found to be $20-80 \mathrm{~nm}[61,83,84]$. In paints, an $\mathrm{nTiO}_{2}$ size of $100-450 \mathrm{~nm}$ has been reported $[10,21]$ being either angular or needle shaped $[10,21,72,85-87]$. Due to the photocatalytic property of $\mathrm{nTiO}_{2}$, before its incorporation in NEPs, the surface is commonly coated with agents such as silicon dioxide $\left(\mathrm{SiO}_{2}\right)$, aluminium oxide $\left(\mathrm{Al}_{2} \mathrm{O}_{3}\right)$ and aluminium hydroxide $\left(\mathrm{Al}(\mathrm{OH})_{3}\right)[10,22,70,77,88-90]$. The coating increases the photostability of the ENMs, reduces photoreactivity and the formation of reactive oxygen species and improves dispersion in the product matrix [69,90-93].

\subsection{Zinc Oxide Nanoparticles ( $\mathrm{Zn} \mathrm{O} \mathrm{O})$}

$\mathrm{nZnO}$ is the third highest produced ENM type worldwide because of its wide application as an active ingredient in sunscreens and cosmetic products $[69,72,94,95]$ in textiles, wound healing, anti-haemorrhoids, antibacterial agents and eczema medical treatments $[44,94]$. The myriad applications of $\mathrm{nZnO}$ can be attributed to their high chemical stability and electrochemical coupling, paramagnetic nature, a broad range of radiation absorption and high photostability [44]. $\mathrm{nZnO}$ has also been reported to have the broadest UV protection and is thus utilised as an active ingredient for most of the UV-blocking products available in the markets [95-97].

$\mathrm{nZnO}$ is produced in two crystalline forms, namely wurtzite and zincite [71,98]. The hexagonal wurtzite phase of $\mathrm{nZnO}$ is more stable and is thus widely incorporated in NEPs [71]. Lewicka et al. [99] found that 4 out of 11 sunscreens contained hexagonal wurtzite phase $\mathrm{nZnO}$. Elsewhere, the presence of crystal wurtzite $\mathrm{nZnO}$ was similarly reported [72]. However, Lehutso et al. [10], reported the presence of zincite phase $\mathrm{nZnO}$ in a sunscreen that contained binary $\mathrm{nTiO}_{2}+\mathrm{nZnO}[10]$. Regarding shape and size, $\mathrm{nZnO}$ was reported to be angularly shaped $(20-100 \mathrm{~nm})[10,69,99,100]$ and rod shaped $[10,69,79,101]$.

\subsection{Silver Nanoparticles $(n A g)$}

Silver has long been known for its antimicrobial properties [102] and nAg has, accordingly, been widely utilised in NEPs, largely for disinfecting purposes [103-105]. nAg has gained popularity in recent years as the preferred silver derivative for use in NEPs because of its increased bioavailability, high specific surface area and a high fraction of surface atoms [106]. The maximised surface area of $\mathrm{nAg}$ means the highest possible effect per unit silver compared to bulk forms [107]. The antimicrobial nature and subsequent extensive application of $\mathrm{nAg}$ are mainly influenced by their broad-spectrum antibacterial and antifungal activity [108].

Though there is still an ongoing debate on the antibacterial mode of action of nAg [106], it has been observed that bulk Ag can precipitate bacterial cellular proteins and block the respiratory chain system, while $\mathrm{nAg}$, because of its small size, attaches itself to the bacterial cell membrane and penetrates internally where it generates oxidative stress, thus eliminating the bacteria [109]. In essence, bulk Ag toxicity depends on the release of ionic $\mathrm{Ag}+$, whereas $\mathrm{nAg}$ effectiveness is additionally linked to the release of free radicals (i.e., oxidative stress induction) even under limited dissolution [106,110-114]. The large surface area of $\mathrm{nAg}$ also facilitates its exposure to $\mathrm{O}_{2}$ and enhances the dissolution and sorption of ionic species [104]. However, the $\mathrm{nAg}$ mode of toxicity for some biota has not been described, although dissolution-linked toxicity has been reported in aquatic higher plants $[115,116]$. Thus far, $\mathrm{nAg}$ has been used in a variety of commercial NEPs such as soaps, pastes, toothbrushes and textiles [25,103,117-120], paints [23,121], cleaning products [122] and washing machines [123].

The physicochemical properties of $\mathrm{nAg}$ in textiles have been reported to be in the range of $\sim 10-100 \mathrm{~nm}$, with near-spherical, spherical and irregular shapes $[10,24,124-126]$. In one report, the zeta potential of $\mathrm{nAg}$ was reported to be negative $(-16.3 \pm 0.5 \mathrm{mV})$ [124]. In paints, $\mathrm{nAg}$ was determined to be $<15-100 \mathrm{~nm}[23,127]$. $\mathrm{nAg}$ in household surface cleaners was reported to be in the range of $<10-101 \mathrm{~nm}$ [128-130] in quasi-spherical, and spherical shapes $[128,129]$. The nAg zeta potential range in household surface cleaners has been reported at -38.6 to $-54 \mathrm{mV}$ [130]. 


\subsection{Silicon Dioxide Nanoparticles $\left(n \mathrm{SiO}_{2}\right)$}

The application of $\mathrm{nSiO}_{2}$ in NEPs is rapidly growing with an estimated 198-kilo tons consumed in 2015 and expected to rise to 786-kilo tons by 2022 [52]. The utilisation of $\mathrm{nSiO}_{2}$ in NEPs is predominantly for properties including anti-caking, anti-baking, increased absorption and self-cleaning, transparency and abrasion resistance $[7,131] . \mathrm{nSiO}_{2}$ is incorporated as an auxiliary material in paper and textile manufacturing [132], food additives [132,133], paints [134], as a pharmaceutical skin treatment for insect bites [135], glass cleaning products [135] and cosmetics (eye creams and hair care products) $[7,10]$.

The relative ease of $\mathrm{nSiO}_{2^{\prime}} \mathrm{s}$ surface modification is one of the practical properties that promotes application in a wide spectrum of NEPs' categories $[7,132,134,136]$. Furthermore, $\mathrm{nSiO}_{2}$ has hydrophilic-hydrophobic characteristics [2] and also exhibits high stability and compatibility with other polymers and molecules [136]. Due to their transparency, $\mathrm{nSiO}_{2}$ are also incorporated as additives in printer toners, varnishes, paint and food [137] The extensive application of $\mathrm{nSiO}_{2}$ in NEPs suggests notable environmental release potential.

While $\mathrm{nSiO}_{2}$ has a relatively wide utilisation in NEPs, their physicochemical properties remain undetermined. In the study of Lehutso et al. [10], an NEP labelled as containing $\mathrm{nSiO}_{2}$ was found to not contain it [10]. Currently, the data on the physicochemical properties of $\mathrm{nSiO}_{2}$ in NEPs remain poorly known, and the status is likely due to its generally low hazard potential; hence, the limited interest in examining its environmental consequences and the priority being afforded to counterparts that are suspected or known to exhibit negative consequences.

\section{Release of ENMS from NEPs}

The ENMs in NEPs may not be permanently fixed into the products matrix, and along the product life cycle, ENMs can be released into the environment $[25,40,91,101,120,138]$. However, data on the characteristics and level of release extent of product released ENMs (PR-ENMs) are currently limited.

By 2017, 96 studies had been undertaken to examine the release of ENMs from NEPs into the environment [20], although, of those, only 36 contained relevant quantitative data, indicating significant gaps in ENMs' environmental exposure dynamics. Koivisto et al. [20] reviewed 36 studies covering all environmental recipients and focused on developing a library of released concentrations [20]. Since then, additional studies have been published and are included in this review.

Herein, we only reviewed PR-ENMs' environmental exposure data specific to aquatic environments, reporting on release methods and physicochemical properties observed. For aquatic exposure, thus far, ENMs' release has been investigated from sunscreens, personal care products, paints, textiles/clothing, washing machine, baby products and toothbrushes (Table 2).

\subsection{Sunscreens}

Sunscreens are commonly formulated with $\mathrm{nTiO}_{2}$ and $\mathrm{nZnO}$, and several studies have examined the release of the ENMs using various methods. In one of the early studies [70], $\mathrm{nTiO}_{2}$ was released from different sunscreens by agitation under light and dark conditions over $48 \mathrm{~h}$. Total Ti released from the sunscreens ranged from 19-32 $\mathrm{wt} \%$ (dark condition) and $22-38 \mathrm{wt} \%$ light conditions. The $\mathrm{PR}-\mathrm{nTiO}_{2}$ were needle-like shaped, averaging $50 \times 10 \mathrm{~nm}$ (width $\times$ length) in size, rutile form and negatively charged. The PR-nTiO also aggregated up to 50-200 $\mathrm{nm}$ [59]. Nthwane et al. [22] mimicked bathing conditions with tap and deionised (DI) water to examine $\mathrm{nTiO}_{2}$ release from three sunscreens [22]. The total released Ti was, respectively, 1.16 and $0.7 \mu \mathrm{g} / \mathrm{L}$ in DI water and tap water. The $\mathrm{PR}-\mathrm{nTiO}_{2}$ were needle-like in morphology and sized 32.1-102.8 $\mathrm{nm}$ and $77.6-139.6 \mathrm{~nm}$ in DI water and tap water, respectively [22].

Wong et al. [100] examined the release of PR-nZnO from sunscreen use in seawater where $0.5 \mathrm{~g}$ of sunscreen was applied to the hands of human volunteers for $20 \mathrm{~min}$ and washed off through soaking in artificial seawater for another $20 \mathrm{~min}$ [100]. The PR-ENMs 
release rate was in the order of $8-72 \%$ [100]. No further characterisation was undertaken after release.

Elsewhere, $\mathrm{nTiO}_{2}$ and $\mathrm{nZnO}$ were released by applying sunscreen on pigskins and washing them off by stirring in tap water [76]. From the liquid type sunscreen, ca. $40 \%$ of the initial loading of ENMs $\left(\mathrm{nZnO}\right.$ and $\left.\mathrm{nTiO}_{2}\right)$ in the sunscreen was released, while the cream type sunscreen released only $20 \%$ of the initial ENMs' $\left(\mathrm{nZnO}\right.$ and $\left.\mathrm{nTiO}_{2}\right)$ loading after 120 min of stirring. These findings illustrated that the NEPs' matrix influences ENMs' release potential as relatively higher concentrations were released from liquid compared to cream matrix sunscreen. A swimming pool simulation in a similar study further indicated that sunscreens may introduce hydrogen peroxide into the water system [76], free radical species that cause adverse effects on aquatic organisms [139]. A recent study aged a sunscreen through an agitation process over $48 \mathrm{~h}$ to characterise the release of ENMs from three sunscreens [140]. Approximately $0.4-8 \%(w / w)$ of the sunscreen's initial loading of $\mathrm{nTiO}_{2}$ and $\mathrm{nZnO}$ was released [140]. One sunscreen contained both $\mathrm{nTiO}_{2}$ and $\mathrm{nZnO}$; the released $\mathrm{nTiO}_{2}$ were elongated, while $\mathrm{nZnO}$ was angular in shape. The two other sunscreens released $\mathrm{nTiO}_{2}$ that was angularly shaped [140]. The sizes of released ENMs from the mixture sunscreen were 32-36 $\times 32-40 \mathrm{~nm}$ and 7-9 $\times 66-70 \mathrm{~nm}$ (width $\times$ length) for $\mathrm{nZnO}$ and $\mathrm{nTiO}_{2}$, respectively [140]. The sizes of $\mathrm{PR}-\mathrm{nTiO}_{2}$ were 2-30 $\times 33-37$ and $21-22 \times 25-28 \mathrm{~nm}$ for sunscreen two and three, respectively. All ENMs released were negatively charged and were suggested to be coated with $\mathrm{Al}$ and Si-based surface coatings. Overall, the physicochemical properties of $\mathrm{PR}-\mathrm{nTiO}_{2}$ and $\mathrm{PR}-\mathrm{nZnO}$ were relatively similar across the studies, and where differences occurred, were due to factors such as the release method and nature (formulation and matrix) of the NEPs.

Table 2. The total concentrations released from different nano-enabled products (NEPs). ENMs = engineered nanomaterials.

\begin{tabular}{|c|c|c|c|}
\hline NEP & ENMs Type & Concentration/Percentage Released & References \\
\hline \multirow{4}{*}{ Sunscreen } & $\mathrm{nTiO}_{2}$ & $\begin{array}{c}7 \times 10^{-4}-0.00116 \mathrm{mg} / \mathrm{L} \\
19-38 \%\end{array}$ & $\begin{array}{l}{[22]} \\
{[70]}\end{array}$ \\
\hline & $\mathrm{nZnO}$ & $0.58 \mathrm{mg} / \mathrm{L}$ & {$[100]$} \\
\hline & \multirow{2}{*}{$\mathrm{nTiO}_{2}+\mathrm{nZnO}$} & $20-40 \%$ & [76] \\
\hline & & $0.4-8 \%$ & [140] \\
\hline \multirow{6}{*}{ Paint } & \multirow{3}{*}{$\mathrm{nAg}$} & $0.5-20 \mathrm{mg} / \mathrm{L}$ & [23] \\
\hline & & $3.5 \times 10^{7}$ particles $/ \mathrm{L}$ & {$[13]$} \\
\hline & & $1.7-15.7 \mu \mathrm{g} / \mathrm{L}$ & {$[121]$} \\
\hline & \multirow{3}{*}{$\mathrm{nTiO}_{2}$} & $5 \times 10^{5}$ particles $/ \mathrm{mL}$ & [127] \\
\hline & & $2 \times 10^{6}-1.2 \times 10^{7} \mu \mathrm{g} / \mathrm{m}^{2}$ & [74] \\
\hline & & $10-30 \mu \mathrm{g} / \mathrm{m}^{2}$ & [87] \\
\hline \multirow{10}{*}{ Textiles } & \multirow{2}{*}{$\mathrm{nTiO}_{2}$} & $0.64-4.7 \mathrm{mg} / \mathrm{L}$ & [120] \\
\hline & & $0.05 \pm 0.02-3.13 \pm 1.51 \mu \mathrm{g} / \mathrm{g}$ & {$[83]$} \\
\hline & \multirow{8}{*}{$\mathrm{nAg}$} & $0.32-38.5 \mathrm{mg} / \mathrm{L}$ & [120] \\
\hline & & $<1-100 \%$ & [14] \\
\hline & & $0.3-377 \mu \mathrm{g} / \mathrm{g}$ & [15] \\
\hline & & $18 \pm 2-2925 \pm 10 \mathrm{mg} / \mathrm{kg}$ & {$[138]$} \\
\hline & & $3.4 \pm 0.1-106 \pm 10 \mu \mathrm{g} / \mathrm{g}$ & [124] \\
\hline & & $15.8-34 \mu \mathrm{g}$ & [141] \\
\hline & & $1 \times 10^{-3}-5.969 \mathrm{mg} / \mathrm{L}$ & {$[24]$} \\
\hline & & $5.3-6.4 \mathrm{mg} / \mathrm{L}$ & {$[126]$} \\
\hline \multirow{2}{*}{$\begin{array}{l}\text { Washing machine } \\
\text { Baby products }\end{array}$} & \multirow{2}{*}{$\begin{array}{l}\mathrm{nAg} \\
\mathrm{nAg}\end{array}$} & $8.1724 \times 10^{7}$ particles $/ \mathrm{mL}$ & [123] \\
\hline & & $1-35 \%$ & [142] \\
\hline \multirow{2}{*}{ Toothbrush } & \multirow{2}{*}{$\mathrm{nAg}$} & 3.6-6.6 × 10 $0^{7}$ particles $/ L$ (Baby) & [25] \\
\hline & & $9.3-20.3 \times 10^{7}$ particles $/ \mathrm{L}$ (Adult) & [25] \\
\hline
\end{tabular}




\subsection{Personal Care Products}

Mackevica et al. [83] investigated the release of nAg from adults' and children's toothbrushes during use [25]. A baby toothbrush and an adult toothbrush were immersed in tap water and fixed on a rotating rod for $24 \mathrm{~h}$. $\mathrm{nAg}$ release from toothbrushes was 9.3-20.3 $\times 10^{7}$ particles/L and 3.6-6.6 $\times 10^{7}$ particles/L for adults' and baby's toothbrushes, respectively. The nAg particle size ranged between 42 and $47 \mathrm{~nm}$ and was spherical [25]. Benn et al. [141] reported 100\% Ag release from toothbrushes of their initial silver loading.

$\mathrm{nAg}$-containing sanitiser and body cream (incorporated with $\mathrm{nAg}$ and binary $\mathrm{nAg}+\mathrm{nTiO}_{2}$ ) were investigated for the release of ENMs using different methods [140]. Briefly, the release from the body cream was conducted using an ageing process over $48 \mathrm{~h}$ under light and dark conditions, while the release from the hand sanitiser was through agitation over $24 \mathrm{~h}$. The sanitiser's PR-nAg were near-spherical shaped and sized $10-23 \mathrm{~nm}$, whereas the body cream's $\mathrm{PR}-\mathrm{nTiO} \mathrm{O}_{2}$ was elongated in shape with a size range of 8-9 $\pm 3 \times 60-66 \pm 9 \mathrm{~nm}$ (width $\times$ length) and associated with Si-based coating agents. Similar to the sanitiser, PR-nAg from body cream was near-spherical and had an average size of $12-55 \mathrm{~nm}$. The PR-ENMs of both the sanitiser and body cream were negatively charged: $-32.5 \pm 2.1 \mathrm{mV}$ for sanitiser and $-23.6 \pm 1.3$ and $-22.8 \pm 1.2 \mathrm{mV}$ for the body cream in light and dark conditions, respectively [140].

These studies indicate that the introduction of $\mathrm{nAg}$ into the environment is possible during use. However, the released concentrations may be lower; contrary to the method used here, the realistic release does not occur continuously over $24 \mathrm{~h}$. Nonetheless, the data presented in these studies provide the starting point for methodology development and optimisation.

\subsection{Paints}

The release of ENMs from paints has been investigated by numerous studies $[15,25,79,94,134,140]$. The release of $\mathrm{nTiO}_{2}$ from paint into surface waters was investigated using painted outdoor façades [13]. One outdoor façade was painted two years prior to the investigation (aged), and the other was painted during the experimental investigation. The runoff from both façades were collected and analysed for $\mathrm{nTiO}_{2}$. In the samples from the aged façade, particles in the range of 50-200 nm were detected. Particles with sizes $<100 \mathrm{~nm}$ had a concentration of $3.5 \times 10^{7}$ particles/L [13]. The amount of $\mathrm{nTiO}_{2}$ was higher in the experimental façade compared to the aged façade.

Kaegi et al. [23] also investigated the release of $\mathrm{nAg}$ from paint applied on outdoor building façade panels that were exposed to natural weathering over a year, and the runoff was collected and analysed for $\mathrm{nAg}$ [23]. The total Ag released in the runoff was determined to be between 0.5 and $20 \mathrm{mg} / \mathrm{L}$ over the exposure period, and there was an average loss of about $30 \%$ of the initially applied surface $\mathrm{Ag}\left(1.5 \mathrm{mg} / \mathrm{m}^{2}\right)$. The PR-nAg was detected as individual particles of $<15 \mathrm{~nm}$ in size in the runoff. However, the amount of $\mathrm{nAg}$ detected in the TEM grids was not sufficient for further characterisation.

Similarly, Künniger et al. [121] used wooden façade panels to evaluate the release of $\mathrm{nAg}$ from paint exposed to outdoor conditions for one year [121]. The runoff was collected after every rainfall during the exposure period, and the total Ag concentration released after three months was $0.67 \mu \mathrm{g} / \mathrm{L}$. During the first three months of exposure, the average Ag concentration released from one of the façade panels ranged between 1 and $21 \mu \mathrm{g} / \mathrm{L}$. The total concentration of Ag released in the runoff from the second sampling varied between 0.08 and $0.86 \mu \mathrm{g} / \mathrm{L}$. The total amount of $\mathrm{nAg}$ released from the wooden façade panels was 15.7 and $1.7 \mu \mathrm{g} / \mathrm{L}$ for the first and second panel, respectively, both accounting for less than $1 \%$ of the $\mathrm{nAg}$ in the initial coating. Neither nanoparticle tracking analysis (NTA) nor TEM were suitable for the further characterisation of particulate Ag in the runoff due to very low detection.

Kaegi et al. [127] examined the release of $\mathrm{nTiO}_{2}$ from paints on construction and demolition landfill discarded materials [127]. The leachate samples contained spherical 
$\mathrm{nTiO}_{2}$ with sizes of $100-150 \mathrm{~nm}$, and the average concentration of the PR-nTiO 2 was reported to be $5 \times 10^{5}$ particles $/ \mathrm{mL}$. The release of $\mathrm{nTiO}_{2}$ from paints was also investigated under actual weathering conditions [85]. The $\mathrm{PR}-\mathrm{nTiO}_{2}$ was analysed in the collected precipitate made up of mainly snow and rain that had come in contact with painted panels over 10 weeks. Considerable amounts of $\mathrm{PR}-\mathrm{nTiO}_{2}$ were obtained in the collected precipitate samples; the $\mathrm{PR}-\mathrm{nTiO}_{2}$ concentration averaged $2-4 \times 106$ particles $/ \mathrm{mL}$ in summer and $8.1 \times 105$ particle $/ \mathrm{mL}$ to $1.2 \times 107$ in winter. Overall, $55 \%$ of $\mathrm{PR}-\mathrm{nTiO} 2$ was quantified and sized $<60 \mathrm{~nm}$.

Azimzada et al. [74] examined ENMs' release from the weathering of painted and stained surfaces under different conditions over 23 weeks (11 weeks in fall and 12 weeks in winter) [74]. The painted surfaces released a total of $\mathrm{Ti}$ at $10 \mu \mathrm{g} / \mathrm{m}^{2}$ by the end of the fall weathering (11 weeks) and significantly less than $10 \mu \mathrm{g} / \mathrm{m}^{2}$ at the end of the winter weathering (12 weeks). The average size of released PR- $\mathrm{nTiO}_{2}$ was $<60 \mathrm{~nm}(15-120 \mathrm{~nm})$. The stained surfaces released over $30 \mu \mathrm{g} / \mathrm{m}^{2} \mathrm{PR}-\mathrm{nTiO}_{2}$ with a size range of $15-100 \mathrm{~nm}$. Overall, the total release accounted for $5 \times 10-5 \%$ for painted surfaces and $6 \%$ for stained surfaces. The differences in the amount released were affected by the chemistry of the NEPs; the exterior wood stain had smaller particles that were more susceptible to leaching than the pure enamel paint [66]. It is evident that the release of ENMs from paints into the environment occurs, although at low concentrations. The studies on paint, as reported here $[25,125,134,140]$, show a relatively lower total release when compared to the more rapid release studies [70,76]. While the complexity of the paint matrix, especially when it is already dry, influences the ENMs' release, the environmental conditions to which the test samples were exposed also influence the release.

\subsection{Clothing/Textile}

Several studies have investigated the release of $\mathrm{nAg}$ and $\mathrm{nTiO}_{2}$ from textiles. $\mathrm{nTiO}_{2}$ release was evaluated from six sun-protection textiles during washing [101]. The textiles released a total $\mathrm{Ti}$ of $<0.7-4.7 \mathrm{mg} / \mathrm{L}$ in the washing solution and $0.64 \mathrm{mg} / \mathrm{L}$ in the subsequent rinsing solution [101]. A higher amount of total Ti was detected in the first wash and gradually reduced with the latter washes. $\mathrm{nTiO}_{2}$ release from synthetic textiles such as wet wipes and microfiber clothes has also been assessed [83], and 0.05 $\pm 0.02-3.13 \pm 1.51 \mu \mathrm{g} / \mathrm{g}$ total Ti was released from the $24-\mathrm{h}$ study. However, only $1 \%$ of the initial $\mathrm{TiO}_{2}$ content released was in the nanoparticulate form.

Elsewhere, the $\mathrm{nAg}$ released from commercial socks in water was investigated using a laboratory washing method [14]. Socks were washed several times and nAg in the release matrix was measured and characterised. The Ag that leached into water ranged from $1.5-650 \mu \mathrm{g}$ in $500 \mathrm{~mL}$ of distilled water. The total silver release ranged from $<1 \%$ in some socks to $100 \%$ of the initial silver loading in other socks. Most of the released Ag was in the ionic form $\left(\mathrm{Ag}^{+}\right)$[16]. Elemental $\mathrm{Ag}$ particles were detected in the release matrix with diameters of 100-500 nm in three of the types of socks. Particles of sizes $<100 \mathrm{~nm}$ were of irregular and spherical shapes [14].

$\mathrm{nAg}$ release from socks and other nine commercially available fabrics were investigated [15]. Total Ag released was quantified in the release media. Four out of the nine fabrics did not release quantifiable levels of $\mathrm{Ag}^{+}$into the water. The total $\mathrm{Ag}$ release from the other five fabrics ranged from 1.3 to 35\%, with the amount of Ag released decreasing with subsequent washes [15]. The concentration of released Ag ranged from 0.3 to $377 \mu \mathrm{g} / \mathrm{g}$ [15].

The release of $\mathrm{nAg}$ from textiles has also been investigated on eight textile products, with the initial Ag content of 1.5-2925 mg/ $\mathrm{kg}$ of textile that were washed and rinsed and the wash water analysed for total released Ag [120]. The Ag concentrations in the wash water and rinsing solution were determined to be $0.32-38.5 \mathrm{mg} / \mathrm{L}$ and $0.36-22.7 \mathrm{mg} / \mathrm{L}$, respectively, indicating the release of 15-20\% [120]. Elsewhere, a standard laboratory method was used to release $\mathrm{nAg}$ from five textiles [138]. The textiles released $18 \pm 2-2925 \pm 10 \mathrm{mg} / \mathrm{kg}$ total Ag; the highest release was approximately $80 \%$ relative to the initial silver incorporated on/in the textile. In another study, $\mathrm{nAg}$ release from four textiles was evaluated by simu- 
lating the washing of fabrics [124]. Accordingly, Ag0-coated textile released $106 \pm 10 \mu \mathrm{g} / \mathrm{g}$, which accounted for $26 \%$ of the initial silver loading. The $\mathrm{nAg}$ textile released $18 \pm 3 \mu \mathrm{g} / \mathrm{g}$, which was $76 \%$ of the initial silver loading after four washes. The textile was washed two additional times and released $3.4 \pm 0.1 \mu \mathrm{g} / \mathrm{g}, 14 \%$ of the initial loading and $90 \%$ release over six washes. Benn et al. [141] used tap water to wash face masks and shirt fabrics containing $\mathrm{nAg}$ for $1 \mathrm{~h}$ [141]. The face mask released a total $\mathrm{Ag}$ of $15.8 \mu \mathrm{g} / \mathrm{mL}$ into the wash water $(<0.01 \%$ of the initial loading), while the shirt released $34 \mu \mathrm{g} / \mathrm{mL}(2 \%$ of the initial loading).

Four textiles containing nAg (cleaning cloth, bodysuit, car sheet, nursing cover) were washed sequentially for 20 consecutive cycles by an agitation method for $30 \mathrm{~min}$ per cycle to evaluate nAg release [24]. The total Ag release was 1-5969 $\mu \mathrm{g} / \mathrm{L}$, with the concentrations decreasing with the increasing number of cycles. Over $50 \%$ of the Ag content was lost from the bodysuit and the car sheet after 20 cycles, while the cleaning fabric lost only $30 \%$ of the initial Ag loading. The released nAg size was 3-5 nm. Gagnon et al. [126] released nAg from socks using actual walking and running conditions [126]. Six people were required to wear the socks without washing, three people walked 8-16 km per week over three weeks, and three others ran for $1 \mathrm{~h}$ per week over 3 weeks wearing the socks. After the walk/run periods, the socks were washed in tap water using a liquid detergent and rinsed. The nAg released after the first wash was $6.4 \mathrm{mg} / \mathrm{L}$ from walking socks and $5.3 \mathrm{mg} / \mathrm{L}$ from running socks [126]. There was no significant difference in the released $\mathrm{nAg}$ concentration between the first and the second wash, and the average size of PR-nAg was ca. 50-200 nm [126].

The various studies reviewed herein provide evidence of ENMs released from textiles (nAg and $\mathrm{nTiO}_{2}$ ) into aquatic environments at various stages of use of these fabric products. The extent of ENMs' release was influenced by the washing cycles, manner of product use, application of wash detergent and initial ENMs' loading. An aspect that needs further examination is the influence of washing detergents on the released ENMs' physicochemical characteristics and release extent as there are suggestions of such influence [20] and also to obtain realistic ENMs' release characteristics. Additionally, the influence of fabric softness is yet to be investigated.

\subsection{Washing Machine}

Farkas et al. [123] investigated the release of nAg from a nano-enabled washing machine (release from machine usage) [123]. The washing machine effluent was analysed for either $\mathrm{nAg}$ or ionic silver after fabric wash or use of the silver function. The results showed that $\mathrm{nAg}$ concentrations in the effluent were 8.17-8.29 $\times 107$ particles $/ \mathrm{mL}$ [123]. Based on this data, future studies should also look exclusively at how much of the nAg in the effluent matrix is from the test material and how much is from the washing machine. While the machine used in this study had a specific silver function, the latter point remains.

\section{Presence of PR-ENMs in Environmental Water Systems}

The PR-ENMs enter natural water environments from various sources, predominantly wastewater treatment works; hence, the need to assess the extent and forms of nanopollution in such settings.

Reed et al. [143] examined $\mathrm{nTiO}_{2}$ release from sunscreens in surface water arising from recreational activity [143]. Samples collected downstream during the highest recreational activity showed increased total $\mathrm{Ti}$ concentrations compared to the background (natural) $\mathrm{Ti}$ in the lake ( 10 ng/L increase). The total concentration of Ti was $0.4-110 \mathrm{ng} / \mathrm{L}$ with size estimated around $79 \mathrm{~nm}$.

Elsewhere, a sampling campaign was carried out in Dutch surface waters to trace ENMs' release [144]. Water samples collected from 15 points were analysed for PR-nAg, $\mathrm{PR}-\mathrm{nTiO} \mathrm{O}_{2}$ and $\mathrm{PR}-\mathrm{nCeO} \mathrm{O}_{2}$ using spICP-MS. The total $\mathrm{Ag}$ in the river samples was quantified to be $0.3-6.6 \mathrm{ng} / \mathrm{L}, \mathrm{nAg}$ size averaged $15 \mathrm{~nm}$ and the $\mathrm{nAg}$ measured environmental concentration (MEC) was determined to be $0.00004-0.619 \mu \mathrm{g} / \mathrm{L}$. The $\mathrm{nAg}$ size was comparable to the waste emissions from textile products that contained $\mathrm{nAg}$; hence, such products were 
probable sources of $\mathrm{nAg}$ accumulation in the two river systems. In the same study, $\mathrm{nTiO}_{2}$ was detected in river samples and the total Ti was $0.2-8.1 \mu \mathrm{g} / \mathrm{L}$, whereas $\mathrm{nTiO}_{2}$ size was 250-340 nm. The sources of the determined $\mathrm{TiO}_{2}$ were linked to microscale pigments in paints and dyes with the particle size corresponding to the application of $\mathrm{nTiO}_{2}$ in food products, toothpaste, sunscreens, cosmetics and drugs. Hence, it can be deduced that these products contributed to the emission of $\mathrm{nTiO}_{2}$ in the two river systems. In a different study [144], PR-nTiO ${ }_{2}$ was not detected in the river Dommel.

The presence of $\mathrm{nTiO}_{2}$ has also been investigated in a lake at the Old Danube recreational area, Vienna, Austria [145]. Samples were collected from the lake during the bathing and the non-bathing seasons [145]. The PR- $\mathrm{nTiO}_{2}$ increased by $40 \%$ at the beginning of the bathing season to an average of $9050 \pm 3940$ particles $/ \mathrm{mL}$ from $5610 \pm 1200$ particles $/ \mathrm{mL}$ during the non-bathing season. The size detection limit was set at $130 \mathrm{~nm}$ (lower limit) and $\mathrm{PR}-\mathrm{nTiO} \mathrm{O}_{2}$ was confirmed to exist as heteroaggregates; the $\mathrm{PR}-\mathrm{nTiO} \mathrm{O}_{2}$ samples were linked to the sunscreen release during bathing [145].

The release of sunscreen ENMs has been examined from bathing activities in the French Mediterranean [146]. The $\mathrm{PR}-\mathrm{nTiO}_{2}$ and $\mathrm{nZnO}$ were detected at elevated amounts during high recreational activity. Total Ti and Zn were, respectively, quantified to be 70-500 and $10-15 \mu \mathrm{g} / \mathrm{L}$ in the top surface water and $10-30$ and $3 \mu \mathrm{g} / \mathrm{L}$ in the water column. The particles were recovered as aggregates in the water but were not characterised further.

The confirmation of PR-ENMs in the aquatic environment confirms the occurrence of nanopollution arising from NEPs. However, in most reports, the current nanopollution concentrations are still relatively low but within the range that may affect some sensitive biota (e.g., microbial communities). Furthermore, while the current amounts are still low, the rapidly rising commercialisation of NEPs will probably be accompanied by increasing nanopollution.

Currently, ENMs are not included in routine environmental monitoring programmes due to weak analytical instrumentation and understanding of their exposure and effects; hence they are considered a case of emerging environmental contaminants. In that context, hotspots should be identified and set as priority monitoring sites to provide more clarity on ENMs' behaviour, fate and effects in aquatic systems, including refining analytical capability.

\section{Ecotoxicity of PR-ENMs in the Aquatic Environment}

In recent years, concerns have been raised about the toxicity of PR-ENMs in the aquatic environment $[25,121,147]$. This is because there is a rapid increase in NEPs' global markets and usage [3]. Consequently, the environmental release of PR-ENMs is inevitably rising.

\subsection{Sunscreen-Released ENMs}

A study using a whole product of sunscreen that contained $\mathrm{nZnO}$ as an active ingredient evaluated the sunscreen ecotoxicity on copepod Tigriopus japonicus (T. japonicus) [94]. T. japonicas copepods were exposed to three brands of sunscreen in $4 \mathrm{~mL}$ of test solutions for over $96 \mathrm{~h} \mathrm{[100].} \mathrm{One} \mathrm{of} \mathrm{the} \mathrm{sunscreen} \mathrm{brands} \mathrm{induced} \mathrm{the} \mathrm{highest} \mathrm{toxicity} \mathrm{to} \mathrm{the} \mathrm{cope-}$ pod species, possibly because of $\mathrm{PR}-\mathrm{nZnO}$ and released $\mathrm{Zn}^{2+}$ [100]. Although significant toxicity was recorded for two of the sunscreen brands, it was observed that the toxicity of $\mathrm{nZnO}$ and $\mathrm{Zn}^{2+}$ were only partial; other sunscreen components may have contributed to copepod mortality. The median lethal concentration $\left(\mathrm{LC}_{50}\right)$ range was $22.4-230 \mathrm{mg} / \mathrm{L}$ depending on the product brand [100].

Similarly, the ecotoxicological response was also evaluated in marine species, namely, Paracentrotus lividus, Phaeodactylum tricornutum, Corophium orientalis, to two types of sunscreens: a chemical-based sunscreen and an organic formulation consisting of metal oxides in their nanoform $\left(\mathrm{nTiO}_{2}\right.$ and $\left.\mathrm{nZnO}\right)$ [148]. The organisms were exposed to the sunscreen in standard saline water and salinity stress at the highest concentrations of $100 \mu \mathrm{L} / \mathrm{L}$. The effective median concentration $\left(\mathrm{EC}_{50}\right)$ for P. tricornutum (chemical sunscreen and nanoformulation), C. orientalis (chemical sunscreen), C. orientalis (nanoformulation) and P. lividus (nanoformulation) was determined to be $96 \mu \mathrm{L} / \mathrm{L}$ under standard salinity after 
exposure [148]. P. lividus exposed to nanoformulation sunscreen exhibited an $\mathrm{EC}_{50}$ of $14 \mu \mathrm{L} / \mathrm{L}$ [148]. The nanoformulation sunscreen showed significantly higher toxicity than the chemical-based sunscreen for crustaceans but significantly lower toxicity for algae when compared to the chemical-based sunscreen [148]. Under salinity stress, the $\mathrm{EC}_{50}$ for C. orientalis was $87 \mu \mathrm{L} / \mathrm{L}$ for the nanoformulation sunscreen and $82 \mu \mathrm{L} / \mathrm{L}$ for the chemicalbased sunscreen [148]. The $\mathrm{EC}_{50}$ were lower in nanoformulation sunscreen for algae and echinoderms: 9.9 versus $48 \mu \mathrm{L} / \mathrm{L}$ for $P$. tricornutum and $16.9 \mu \mathrm{L} / \mathrm{L}$ versus $71.0 \mu \mathrm{L} / \mathrm{L}$ for nanoformulation and chemical-based sunscreens, respectively, indicating higher toxicity for nanoformulation sunscreen under salinity stress [148]. This effectively means that the physicochemical properties of the exposure medium and sunscreen formulation influenced the observed toxicity. In the study [148], salinity enhanced the toxicity and, therefore, should be taken into account during further investigations that are relevant to coastal and marine environments.

\subsection{Household Detergent-Released ENMs}

The bactericidal effects of PR-nAg in mesosilver used in a household detergent (hot tub cleaner) was investigated using Pseudoalteromonas aliena (P. aliena), Cellulophaga fuciola (C. fuciola), Arthrobacter agilis (A. agilis) and Streptomyces koyangensis (S. koyangensis) [122]. The exposures $(0.062-1.5 \mathrm{mg} / \mathrm{L})$ were developed in $50 \mathrm{~mL}$ conical flasks containing $40 \mathrm{~mL}$ low nutrient liquid $\mathrm{ZM} / 10$ solution at $25^{\circ} \mathrm{C}$ in the dark [122]. The PR-nAg inhibited the growth of bacteria at very low concentrations $(0.072 \mathrm{mg} / \mathrm{L})$ and compromised their cell viability [122]. Therefore, the release of $\mathrm{nAg}$ into the aquatic environment has the potential to induce effects on the ecosystem [149].

\subsection{Textile-Released ENMs}

The toxicity effects of textile PR-nAg have been investigated [124,147]. The toxicity effects of socks' PR-nAg was assessed on zebrafish embryos (Danio rerio) [147]. The D. rerio embryos were exposed to undiluted leachate directly from socks and centrifuged leachate over $72 \mathrm{~h}$. Mortality was recorded after $24 \mathrm{~h}$ with $\mathrm{LC}_{50}$ values at 0.4 and $0.26 \mathrm{mg} / \mathrm{L}$ for undiluted leachate and centrifuged leachate, respectively [147]. The nAg-enabled socks ${ }^{\prime}$ derived solutions (undiluted sock and spun sock) further induced hatching inhibition and abnormal embryo development after the 72-h exposure [147]. The extensive toxicity in this study was reported to be likely exacerbated by other components in the exposure media other than nAg. Elsewhere, [124] wash water was used to investigate the effects of textile PR-nAg on zebrafish (Danio rerio). The wash water from a release study reported earlier in the current paper [147] was diluted to different concentrations, and the zebrafish embryo was statically exposed and assessed at 24-h post-fertilisation [124]. In this investigation, no mortality was recorded and the toxicity of PR-nAg on D. rerio embryos could not be validated [124].

\subsection{Paint-Released ENMs}

Künniger et al. [121] evaluated the toxicity of paint PR-nAg where the collected runoff water samples from wooden façades were coated and exposed to the precipitation over one year after rainfall [121]. Toxicity was assessed on algae (Pseudokirchneriella subcapitata), bacteria (Vibrio fischeri) and daphnia (Daphnia magna). The runoff nAg concentrations used for the toxicity assessments were $7.17 \mu \mathrm{g} / \mathrm{L}$ for $V$. fischeri and P. subcapitata and $21.08 \mu \mathrm{g} / \mathrm{L}$ for D. magna [121]. The toxicological assessment showed that PR-nAg had no significant effects on the tested organisms [121].

The widespread application of ENMs points to continued environmental release and exposure, which may reach levels that are detrimental to the environment. Based on the studies reviewed in this paper, it is evident that several factors need to be considered in assessing the toxicity of PR-ENMs. This includes physicochemical transformations of released ENMs to identify the hazard basis. The co-occurrence of ENMs with product components and wastewater parameters (including binary ENMs) is another key aspect as, 
currently, the observed toxicity cannot be attributed to just ENMs. Thus far, the synergistic effects of $\mathrm{nZnO}$ and $\mathrm{nTiO}_{2}$ have been hinted at in this study. However, the impact of binary PR-ENMs is not yet clear and more data still need to be generated on this aspect, although in silico approaches are beginning to provide insights for pristine-ENMs (P-ENMs) [150]. The currently reported aquatic toxicity effects of PR-ENMs discussed in this section are summarised in Table 3.

Table 3. The summary of reported on ecotoxicological data based on PR-ENMs ${ }^{1}$ investigated, surrogate organisms observed effect and $\mathrm{LC}_{50}{ }^{2}$ or $\mathrm{EC}_{50}{ }^{3}$ where reported (continuation).

\begin{tabular}{|c|c|c|c|c|c|}
\hline NEPs Type & ENMs Type & Organism & $\mathrm{LC}_{50}$ or $\mathrm{EC}_{50}$ & Observation & References \\
\hline Sunscreen & $\mathrm{nTiO}_{2}+\mathrm{nZnO}$ & $\begin{array}{l}\text { P. lividus } \\
\text { P. tricornutum } \\
\text { C. orientalis }\end{array}$ & $\begin{array}{c}14-96 \mu \mathrm{L} / \mathrm{L} \text { (standard salinity) } \\
9.9-82 \mu \mathrm{L} / \mathrm{L} \text { (salinity stress) }\end{array}$ & Growth inhibition & [148] \\
\hline Textile & $\mathrm{nAg}$ & D. rerio & $\begin{array}{c}0.26-0.4 \mathrm{mg} / \mathrm{L} \\
*\end{array}$ & $\begin{array}{l}\text { Hatching inhibition } \\
\text { Abnormal embryo } \\
\text { development } \\
\text { No effects }\end{array}$ & $\begin{array}{l}{[147]} \\
{[124]}\end{array}$ \\
\hline Household detergent & $\mathrm{nAg}$ & $\begin{array}{c}\text { P. aliena } \\
\text { C. fuciola } \\
\text { A. agilis } \\
\text { S. koyangensis }\end{array}$ & * & Growth inhibition & [122] \\
\hline Paint & $\mathrm{nAg}$ & $\begin{array}{l}\text { P. subcapitata } \\
\text { V. fischeri } \\
\text { D. magna }\end{array}$ & * & No effects & [121] \\
\hline
\end{tabular}

${ }^{1}$ Product released engineered nanomaterials; ${ }^{2}$ Median lethal concentration, the concentration of a chemical (nanomaterials) that will kill 50 percent of the sample population being investigated; ${ }^{3}$ Effective median concentration, the concentration of a substance in an environmental medium expected to produce an effect in $50 \%$ of test organisms in a given population; ${ }^{*} \mathrm{EC}_{50}$ or $\mathrm{LC}_{50}$ not reported.

Most of the reports used mainly P-ENMs, which leaves considerable information paucity on PR-ENMs toxicity. Therefore, more research is required to understand the release, transport, fate and effects of PR-ENMs. It is evident that ENMs used in products such as sunscreens have high environmental exposure potential, and their effects need to be prioritised.

One of the biggest challenges is the low sample mass and concentrations that are extracted or released from NEPs. While realistic, the low concentrations may not induce any significant effect on the organism, as reported by Künniger et al. [121] and Reed et al. [124]. However, the low concentration of ENMs from one-off experiments does not speak to the cumulative effects of bioaccumulation over time. The ENMs have the potential to accumulate in the aquatic systems and their concentrations over time may increase as a result of PR-ENMs' discharge into these systems, and elongated exposure periods may enhance the ENMs' hazardous effects, although this has not been reported with PRENMs $[47,115,151]$. While the PR-ENMs may induce effects, the toxicity of other product components is a reality that obscures the current PR-ENM data [124,152].

\section{PR-ENMs Risk Characterisation Estimation}

As illustrated in earlier sections, NEPs can be a source of nanopollution in water resources [11,18,42,152]. Despite persistent challenges pertaining to both exposure and hazard assessments, it has become a necessity to initiate efforts to estimate potential risks, considering the data limitations. To estimate the present risk arising from PR-ENMs in aquatic systems, the current section summarised and utilised available release concentrations and ecotoxicological data to derive the PNECs (predicted no effects concentration). The data from the release studies were used as measured environmental concentration (MEC) without factoring in parameters that can influence exposure potentials, such as product use rate and environmental flows. The risk quotient was calculated using the following

$$
R Q=\frac{M E C}{P N E C}
$$


where MEC is the measured environmental concentration; MECs of PR-ENMs are reported in release studies (Table 2). The lowest and highest concentrations of PR-ENMs per NEP type represented the least and worst case scenarios, respectively.

$$
P N E C=\frac{L C_{50}}{A F} \text { or } P N E C=\frac{E C_{50}}{A F}
$$

where $\mathrm{EC}_{50}$ or $\mathrm{LC}_{50}$ is the half-maximal concentration or median lethal concentrations in the ecotoxicological studies reviewed, reported earlier in this paper (Table 3). Similar to MECs, the lowest and highest $\mathrm{EC}_{50}$ or $\mathrm{LC}_{50}$ of PR-ENMs per NEP type represent the worst and least case scenarios, respectively. AF is the assessment factor for any given environmental compartment. The assessment factor of 1000 was applied since all toxicity assessments were examined under acute conditions [18]. The RQ values are interpreted using the following scale: $R Q<1$ means no significant risk, RQ of 1-10 means small adverse effects, RQ of 10-100 means potential adverse effects and $R Q>100$ means significant adverse effects.

Using Equations (1) and (2) and data sets listed in Tables 2 and 3, the RQs of PR-ENMs under different scenarios were determined (Table 4).

Table 4. The PR-ENMs risk characterisation estimates for different organisms.

\begin{tabular}{|c|c|c|c|c|c|c|}
\hline NEPs Type & $\begin{array}{l}\text { Organisms } \\
\text { Group }\end{array}$ & PR-ENMs & $\begin{array}{c}\text { RQ (Least Case } \\
\text { Scenarios) }\end{array}$ & RQ Interpretation & $\begin{array}{l}\text { RQ (Worst Case } \\
\text { Scenarios) }\end{array}$ & RQ Interpretation \\
\hline \multirow{5}{*}{ Sunscreen } & \multirow{2}{*}{ Algae } & $\mathrm{PR}-\mathrm{nTiO}_{2}$ & 0.073 & No significant risk & 34.1 & Potential adverse effects \\
\hline & & $\mathrm{PR}-\mathrm{nZnO}$ & 35.4 & Potential adverse effects & 35.4 & Potential adverse effects \\
\hline & \multirow{2}{*}{ Echinoderms } & $\mathrm{PR}-\mathrm{nTiO}_{2}$ & 0.007 & No significant risk & 0.083 & No significant risk \\
\hline & & $\mathrm{PR}-\mathrm{nZnO}$ & 6.04 & Small adverse effects & 41.4 & Potential adverse effects \\
\hline & Crustacea & $\mathrm{PR}-\mathrm{nZnO}$ & 25.9 & Potential adverse effects & 25.9 & Potential adverse effects \\
\hline Textile & Fish & PR-nAg & 800 & Significant adverse effects & $148,076.9$ & Significant adverse effects \\
\hline
\end{tabular}

The RQs were reported for two NEPs (sunscreen and textiles); the limitation was dictated by the availability of data in the reviewed studies; it is indicative that the risk assessment was hampered by the unavailability or shortage of PR-ENMs' raw data [153]. Modelling studies, therefore, will continue to rely on P-ENMs data [154], which may overestimate or underestimate the risk until the PR-ENMs data gaps (exposure and effects) are addressed.

From Table 4, it can be observed that textile PR-nAg presents the highest RQ for fish (Danio rerio) for both the least and worst case scenario ( $R Q>100)$. According to the $R Q$ scale, textile PR-nAg will therefore have significant adverse effects on fish. The least case scenario RQ (800) is in the range of 100-1000 that warrants further testing to verify the risk [18]. The RQ above 1000 in the worst case scenario means that risk reduction measures should be implemented. However, the data analysed in this paper are only enough to give cautious estimates as there is not enough ecotoxicological data for textile nAg to establish the risk.

Sunscreen $\mathrm{PR}-\mathrm{nTiO}$ showed the $\mathrm{RQ}$ values for crustaceans were $<1$ for both the worst case and least case scenarios. While there is an increase in the $R Q$ values, the increase is low and remains below 1 . For algae, the RQ value was in the range of $10-100$ for PR $-\mathrm{nZnO}$ and $\mathrm{PR}-\mathrm{nTiO}$, but only in the worst case scenario for $\mathrm{PR}-\mathrm{nTiO}_{2}$. There were similar results for crustaceans. The RQ value here means that there are potential adverse effects from sunscreen PR-ENMs to algae over time. Thus, there needs to be a thorough establishment of the potential risks of these PR-ENMs over time; similar sentiments have been raised previously [34].

The risk estimation, as presented herein, is limited by a few factors, mainly by data paucity regarding the release and effects of PR-ENMs. Ecotoxicological studies are also still lacking, and this means the PNEC values are calculated from minimal available data. For instance, the $\mathrm{LC}_{50}$ or $\mathrm{EC}_{50}$ values used to calculate PNECs in this study were limited to a few reports of $\mathrm{EC}_{50}$ or $\mathrm{LC}_{50}$ values (Table 4). Part of that can be attributed to the scarcity of ecotoxicological data that specifically uses PR-ENMs [154]. Secondly, the PR-ENMs' 
concentrations were used as MECs, assuming those would be the concentrations that are released into the environment with transformation and dilution not accounted for. While this helps for risk estimation, the actual measured concentrations in the environment will likely be lower and, thus, the risk is overestimated. However, the risk determination is useful to serve as a guide for NEP cases that may require priority attention concerning the generation of ENMs' exposure and effects. However, the current PR-ENMs' risk estimation was comparable to other modelling studies [34,154], which also found that cosmetics PR-ENMs are expected to pose a significant risk to the aquatic environment.

\section{Conclusions, Recommendations and Future Directions}

Research on PR-ENMs' environmental implication has considerably lagged behind nanotechnology advances; however, data on the PR-ENMs of $\mathrm{nTiO}_{2}, \mathrm{nZnO}, \mathrm{nAg}$ and $\mathrm{nSiO}_{2}$ is starting to grow. The majority of studies investigating the release of ENMs from NEPs commonly report the concentration and/or percentage of ENMs released, but the detailed characterisation of PR-ENMs after release remains rare, partly due to the small sample volume/mass obtainable after conducting release. PR-ENMs' release into aquatic environments has been reported from sunscreens and other cosmetic products, paints, food products and pharmaceutical products. The heteroaggregation of PR-ENMs with other product components and media abiotic factors is a significant analytical challenge that hinders the "nano" hazard identification. The studies so far have predominantly been on freshwater algae, bacteria and invertebrates (daphnia), while a few exist on marine invertebrates and fish embryos.

Critical questions remain about the environmental risks of PR-ENMs in the face of data challenges related to their exposure and effects. To accelerate data solicitation, we recommend the following:

The development of country/region-specific NEPs inventories to serve as the primary basis for the assessment of PR-ENMs' environmental release likelihood. Voluntary reporting of some basic properties of ENMs by manufacturers can enrich such a data collection activity.

The examination of all commercially active NEPs is impractical and unnecessary, hence, detailed release and effects assessment of PR-ENMs should be dedicated to NEPs that exhibit medium to high environmental exposure, as defined by the conditions for a specific geographic region. Additionally, assessments should couple laboratory- and modelling-based studies to advance information generation. It is highly encouraged that release studies incorporate realistic conditions that may be at play at various product life cycle stages (prioritising actual products compared to laboratory formulates). However, comparative assessments in a simple medium are essential to eliminate, as much as possible, biotic and abiotic factors that may be introduced, possibly making data evaluation more complex. For instance, well-characterised laboratory constituted aquatic media can serve as valuable control media for assessment that mimics actual product use. Furthermore, standardised methods for ENMs' release should be developed per product category/type to improve data comparability.

Once PR-ENMs' exposure likelihood has been obtained and ranked, where environmental monitoring is justified, this should be effected in hot spots for environmental release, for instance, wastewater effluents and discharge points, solid waste dumps and demolition sites for construction materials, etc.

Author Contributions: Conceptualisation, M.S.M., R.F.L., M.E., P.J.O., M.T.; methodology, M.S.M., R.F.L., M.E., P.J.O., M.T.; validation, M.T.; formal analysis, M.S.M., R.F.L.; investigation, M.S.M., R.F.L., M.T.; resources, M.T.; data curation, M.S.M., R.F.L., M.T.; writing—original draft preparation, M.S.M.; writing-review and editing, M.S.M., R.F.L., M.E., P.J.O., M.T.; visualisation, M.S.M.; supervision, R.F.L., M.E., P.J.O., M.T.; project administration, M.T.; funding acquisition, M.T. All authors have read and agreed to the published version of the manuscript.

Funding: This research was funded by the South African Department of Science and Technology (DST) under the Nanotechnology Health, Safety and Environment Risk Research Platform (grant number: 0085/2015). 
Data Availability Statement: All data sources are cited, and a citation list is provided.

Conflicts of Interest: The authors declare no conflict of interest.

\section{References}

1. Breznan, D.; Das, D.D.; Mackinnon-Roy, C.; Bernatchez, S.; Sayari, A.; Hill, M.; Vincent, R.; Kumarathasan, P. Physicochemical Properties Can Be Key Determinants of Mesoporous Silica Nanoparticle Potency in Vitro. ACS Nano 2018, 12, 12062-12079. [CrossRef] [PubMed]

2. Adach, K.; Kroisova, D.; Fijalkowski, M. Biogenic silicon dioxide nanoparticles processed from natural sources. Part. Sci. Technol. 2021, 39, 481-489. [CrossRef]

3. BCC Research Global Nanotechnology Market (by Component and Applications), Funding \& Investment, Patent Analysis and 27 Companies Profile \& Recent Developments_Forecast to 2024. Available online: https: / www.researchandmarkets.com/reports / 4520812/global-nanotechnology-market-by-component-and (accessed on 26 July 2021).

4. Vance, M.E.; Kuiken, T.; Vejerano, E.P.; McGinnis, S.P.; Hochella, M.F.; Hull, D.R. Nanotechnology in the real world: Redeveloping the nanomaterial consumer products inventory. Beilstein J. Nanotechnol. 2015, 6, 1769-1780. [CrossRef]

5. Hansen, S.F.; Hansen, O.F.H.; Nielsen, M.B. Advances and challenges towards consumerization of nanomaterials. Nat. Nanotechnol. 2020, 15, 964-965. [CrossRef] [PubMed]

6. Foss Hansen, S.; Heggelund, L.R.; Revilla Besora, P.; Mackevica, A.; Boldrin, A.; Baun, A. Nanoproducts-What is actually available to European consumers? Environ. Sci. Nano 2016, 3, 169-180. [CrossRef]

7. Moeta, P.J.; Wesley-Smith, J.; Maity, A.; Thwala, M. Nano-enabled products in South Africa and the assessment of environmental exposure potential for engineered nanomaterials. SN Appl. Sci. 2019, 1, 577. [CrossRef]

8. Zhang, Y.; Leu, Y.R.; Aitken, R.J.; Riediker, M. Inventory of engineered nanoparticle-containing consumer products available in the singapore retail market and likelihood of release into the aquatic environment. Int. J. Environ. Res. Public Health 2015, 12, 8717-8743. [CrossRef]

9. Amorim, M.J.B.; Lin, S.; Schlich, K.; Navas, J.M.; Brunelli, A.; Neubauer, N.; Vilsmeier, K.; Costa, A.L.; Gondikas, A.; Xia, T.; et al. Environmental Impacts by Fragments Released from Nanoenabled Products: A Multiassay, Multimaterial Exploration by the SUN Approach. Environ. Sci. Technol. 2018, 52, 1514-1524. [CrossRef] [PubMed]

10. Lehutso, R.F.; Tancu, Y.; Maity, A.; Thwala, M. Characterisation of engineered nanomaterials in nano-enabled products exhibiting priority environmental exposure. Molecules 2021, 26, 1370. [CrossRef] [PubMed]

11. Salieri, B.; Turner, D.A.; Nowack, B.; Hischier, R. Life cycle assessment of manufactured nanomaterials: Where are we? NanoImpact 2018, 10, 108-120. [CrossRef]

12. Lehutso, R.F.; Tancu, Y.; Maity, A.; Thwala, M. Aquatic toxicity of transformed and product-released engineered nanomaterials: An overview of the current state of knowledge. Process Saf. Environ. Prot. 2020, 138, 39-56. [CrossRef]

13. Kaegi, R.; Ulrich, A.; Sinnet, B.; Vonbank, R.; Wichser, A.; Zuleeg, S.; Simmler, H.; Brunner, S.; Vonmont, H.; Burkhardt, M.; et al. Synthetic $\mathrm{TiO}_{2}$ nanoparticle emission from exterior facades into the aquatic environment. Environ. Pollut. 2008, 156, 233-239. [CrossRef] [PubMed]

14. Benn, T.M.; Westerhoff, P. Nanoparticle Silver Released into Water from Commercially Available Sock Fabrics. Environ. Sci. Technol. 2008, 42, 4133-4139. [CrossRef] [PubMed]

15. Geranio, L.; Heuberger, M.; Nowack, B. The Behavior of Silver Nanotextiles during Washing. Environ. Sci. Technol. 2009, 43, 8113-8118. [CrossRef] [PubMed]

16. Food and Drug Administration Guidance for Industry: Safety of Nanomaterials in Cosmetic Products I FDA. Available online: https: / / www.fda.gov/regulatory-information/search-fda-guidance-documents/guidance-industry-safety-nanomaterialscosmetic-products\#IIIB1 (accessed on 19 April 2020).

17. Food and Drug Administration Guidance for Considering Whether an FDA-Regulated Product Involves the Application of Nanotechnology FDA. Available online: https:/ / www.fda.gov/regulatory-information/search-fda-guidance-documents / considering-whether-fda-regulated-product-involves-application-nanotechnology (accessed on 19 October 2021).

18. European Commission Joint Research Centre. Technical Guidance Document on Risk Assessment in Support of Commission Directive 93/67/EEC on Risk Assessment for New Notified Substances. Commission Regulation (EC) No 1488/94 on Risk Assessment for Existing Substances Directive 98/8/EC of the European Parliament and of the Council Concerning the Placing of Biocidal Products on the Market. Part II. Available online: https:/ / echa.europa.eu/documents/10162/987906/tgdpart2_2ed_en. pdf/138b7b71-a069-428e-9036-62f4300b752f (accessed on 21 October 2021).

19. Oecd Physical-Chemical Decision Framework to Inform Decisions for Risk Assessment of Manufactured Nanomaterials. Available online: https: / / www.oecd.org/officialdocuments / publicdisplaydocumentpdf / ?cote=env/jm/mono(2019)12\&doclanguage=en (accessed on 28 July 2021).

20. Koivisto, A.J.; Jensen, A.C.Ø.; Kling, K.I.; Nørgaard, A.; Brinch, A.; Christensen, F.; Jensen, K.A. Quantitative material releases from products and articles containing manufactured nanomaterials: Towards a release library. NanoImpact 2017, 5, 119-132. [CrossRef]

21. Al-Kattan, A.; Wichser, A.; Vonbank, R.; Brunner, S.; Ulrich, A.; Zuin, S.; Nowack, B. Release of $\mathrm{TiO}_{2}$ from paints containing pigment- $\mathrm{TiO}_{2}$ or nano- $\mathrm{TiO}_{2}$ by weathering. Environ. Sci. Process. Impacts 2013, 15, 2186. [CrossRef] 
22. Nthwane, Y.B.; Tancu, Y.; Maity, A.; Thwala, M. Characterisation of titanium oxide nanomaterials in sunscreens obtained by extraction and release exposure scenarios. SN Appl. Sci. 2019, 1, 312. [CrossRef]

23. Kaegi, R.; Sinnet, B.; Zuleeg, S.; Hagendorfer, H.; Mueller, E.; Vonbank, R.; Boller, M.; Burkhardt, M. Release of silver nanoparticles from outdoor facades. Environ. Pollut. 2010, 158, 2900-2905. [CrossRef]

24. Limpiteeprakan, P.; Babel, S.; Lohwacharin, J.; Takizawa, S. Release of silver nanoparticles from fabrics during the course of sequential washing. Environ. Sci. Pollut. Res. 2016, 23, 22810-22818. [CrossRef] [PubMed]

25. Mackevica, A.; Olsson, M.E.; Hansen, S.F. The release of silver nanoparticles from commercial toothbrushes. J. Hazard. Mater. 2017, 322, 270-275. [CrossRef] [PubMed]

26. Da Silva, B.F.; Pérez, S.; Gardinalli, P.; Singhal, R.K.; Mozeto, A.A.; Barceló, D. Analytical chemistry of metallic nanoparticles in natural environments. Trends Anal. Chem. 2011, 30, 528-540. [CrossRef]

27. De la Calle, I.; Menta, M.; Séby, F. Current trends and challenges in sample preparation for metallic nanoparticles analysis in daily products and environmental samples: A review. Spectrochim. Acta Part B At. Spectrosc. 2016, 125, 66-96. [CrossRef]

28. Laborda, F.; Bolea, E.; Cepriá, G.; Gómez, M.T.; Jiménez, M.S.; Pérez-Arantegui, J.; Castillo, J.R. Detection, characterization and quantification of inorganic engineered nanomaterials: A review of techniques and methodological approaches for the analysis of complex samples. Anal. Chim. Acta 2016, 904, 10-32. [CrossRef] [PubMed]

29. Amde, M.; Liu, J.; Tan, Z.-Q.; Bekana, D. Transformation and bioavailability of metal oxide nanoparticles in aquatic and terrestrial environments. A review. Environ. Pollut. 2017, 230, 250-267. [CrossRef]

30. Bandyopadhyay, S.; Peralta-Videa, J.R.; Gardea-Torresdey, J.L. Advanced Analytical Techniques for the Measurement of Nanomaterials in Food and Agricultural Samples: A Review. Environ. Eng. Sci. 2013, 30, 118-125. [CrossRef] [PubMed]

31. Zhang, M.; Yang, J.; Cai, Z.; Feng, Y.; Wang, Y.; Zhang, D.; Pan, X. Detection of engineered nanoparticles in aquatic environments: Current status and challenges in enrichment, separation, and analysis. Environ. Sci. Nano 2019, 6, 709-735. [CrossRef]

32. Choi, S.; Johnston, M.; Wang, G.S.; Huang, C.P. A seasonal observation on the distribution of engineered nanoparticles in municipal wastewater treatment systems exemplified by $\mathrm{TiO}_{2}$ and $\mathrm{ZnO}$. Sci. Total Environ. 2018, 625, 1321-1329. [CrossRef] [PubMed]

33. Maryam, B.; Büyükgüngör, H. Wastewater reclamation and reuse trends in Turkey: Opportunities and challenges. J. Water Process Eng. 2019, 30, 100501. [CrossRef]

34. Musee, N. Simulated environmental risk estimation of engineered nanomaterials: A case of cosmetics in Johannesburg City. Hum. Exp. Toxicol. 2011, 30, 1181-1195. [CrossRef] [PubMed]

35. Bathi, J.R.; Moazeni, F.; Upadhyayula, V.K.K.; Chowdhury, I.; Palchoudhury, S.; Potts, G.E.; Gadhamshetty, V. Behavior of engineered nanoparticles in aquatic environmental samples: Current status and challenges. Sci. Total Environ. 2021, $793,148560$. [CrossRef]

36. Martínez, G.; Merinero, M.; Pérez-Aranda, M.; Pérez-Soriano, E.M.; Ortiz, T.; Begines, B.; Alcudia, A. Environmental impact of nanoparticles' application as an emerging technology: A review. Materials 2021, 14, 166. [CrossRef]

37. Heilgeist, S.; Sekine, R.; Sahin, O.; Stewart, R.A. Finding nano: Challenges involved in monitoring the presence and fate of engineered titanium dioxide nanoparticles in aquatic environments. Water 2021, 13, 734. [CrossRef]

38. Ramachandran, G.; Ostraat, M.; Evans, D.E.; Methner, M.M.; O'Shaughnessy, P.; D'Arcy, J.; Geraci, C.L.; Stevenson, E.; Maynard, A.; Rickabaugh, K. A strategy for assessing workplace exposures to nanomaterials. J. Occup. Environ. Hyg. 2011, 8, 673-685. [CrossRef]

39. Ma, H.; Williams, P.L.; Diamond, S.A. Ecotoxicity of manufactured ZnO nanoparticles-A review. Environ. Pollut. 2013, 172, 76-85. [CrossRef] [PubMed]

40. Labille, J.; Catalano, R.; Slomberg, D.; Motellier, S.; Pinsino, A.; Hennebert, P.; Santaella, C.; Bartolomei, V. Assessing Sunscreen Lifecycle to Minimize Environmental Risk Posed by Nanoparticulate UV-Filters-A Review for Safer-by-Design Products. Front. Environ. Sci. 2020, 8, 101. [CrossRef]

41. Shevlin, D.; O'Brien, N.; Cummins, E. Silver engineered nanoparticles in freshwater systems-Likely fate and behaviour through natural attenuation processes. Sci. Total Environ. 2018, 621, 1033-1046. [CrossRef] [PubMed]

42. Nowack, B.; Ranville, J.F.; Diamond, S.; Gallego-Urrea, J.A.; Metcalfe, C.; Rose, J.; Horne, N.; Koelmans, A.A.; Klaine, S.J. Potential scenarios for nanomaterial release and subsequent alteration in the environment. Environ. Toxicol. Chem. 2012, 31, 50-59. [CrossRef] [PubMed]

43. Mitrano, D.M.; Motellier, S.; Clavaguera, S.; Nowack, B. Review of nanomaterial aging and transformations through the life cycle of nano-enhanced products. Environ. Int. 2015, 77, 132-147. [CrossRef] [PubMed]

44. Parihar, V.; Raja, M.; Paulose, R. A brief review of structural, electrical and electrochemical properties of zinc oxide nanoparticles. Rev. Adv. Mater. Sci. 2018, 53, 119-130. [CrossRef]

45. Fytianos, G.; Rahdar, A.; Kyzas, G.Z. Nanomaterials in cosmetics: Recent updates. Nanomaterials 2020, 10, 979. [CrossRef]

46. Adeleye, A.S.; Oranu, E.A.; Tao, M.; Keller, A.A. Release and detection of nanosized copper from a commercial antifouling paint. Water Res. 2016, 102, 374-382. [CrossRef] [PubMed]

47. Hou, J.; Li, T.; Miao, L.; You, G.; Xu, Y.; Liu, S. Effects of titanium dioxide nanoparticles on algal and bacterial communities in periphytic biofilms. Environ. Pollut. 2019, 251, 407-414. [CrossRef] [PubMed]

48. Wu, D.; Yang, S.; Du, W.; Yin, Y.; Zhang, J.; Guo, H. Effects of titanium dioxide nanoparticles on Microcystis aeruginosa and microcystins production and release. J. Hazard. Mater. 2019, 377, 1-7. [CrossRef] 
49. De Leersnyder, I.; Rijckaert, H.; De Gelder, L.; Van Driessche, I.; Vermeir, P. High Variability in Silver Particle Characteristics, Silver Concentrations, and Production Batches of Commercially Available Products Indicates the Need for a More Rigorous Approach. Nanomaterials 2020, 10, 1394. [CrossRef]

50. Szymańska, R.; Kołodziej, K.; Ślesak, I.; Zimak-Piekarczyk, P.; Orzechowska, A.; Gabruk, M.; Zadło, A.; Habina, I.; Knap, W.; Burda, K.; et al. Titanium dioxide nanoparticles (100-1000 mg/L) can affect vitamin E response in Arabidopsis thaliana. Environ. Pollut. 2016, 213, 957-965. [CrossRef] [PubMed]

51. Pulit-Prociak, J.; Banach, M. Silver nanoparticles-A material of the future ... ? Open Chem. 2016, 14, 76-91. [CrossRef]

52. Inshakova, E.; Inshakov, O. World market for nanomaterials: Structure and trends. MATEC Web Conf. 2017, 129, 02013. [CrossRef]

53. Nanodatabase Consumer Products-The Nanodatabase. Available online: https://nanodb.dk/en/analysis/consumer-products/ \#chartHashsection (accessed on 26 July 2021).

54. CPI Consumer Products Inventory: An Inventory of Nanotechnology-Based Consumer Products Introduced on the Market. Available online: https:/ / processwire.com/sites/list/nanotechnology-consumer-products-inventory/ (accessed on 21 October 2021).

55. Tan, C.; Fan, W.H.; Wang, W.X. Role of titanium dioxide nanoparticles in the elevated uptake and retention of cadmium and zinc in Daphnia magna. Environ. Sci. Technol. 2012, 46, 469-476. [CrossRef] [PubMed]

56. Shin, S.W.; Song, I.H.; Um, S.H. Role of physicochemical properties in nanoparticle toxicity. Nanomaterials 2015, 5, 1351-1365. [CrossRef] [PubMed]

57. Ziental, D.; Czarczynska-Goslinska, B.; Mlynarczyk, D.T.; Glowacka-Sobotta, A.; Stanisz, B.; Goslinski, T.; Sobotta, L. Titanium dioxide nanoparticles: Prospects and applications in medicine. Nanomaterials 2020, 10, 387. [CrossRef]

58. Dréno, B.; Alexis, A.; Chuberre, B.; Marinovich, M. Safety of titanium dioxide nanoparticles in cosmetics. J. Eur. Acad. Dermatol. Venereol. 2019, 33, 34-46. [CrossRef]

59. Peters, R.J.B.; van Bemmel, G.; Herrera-Rivera, Z.; Helsper, H.P.F.G.; Marvin, H.J.P.; Weigel, S.; Tromp, P.C.; Oomen, A.G.; Rietveld, A.G.; Bouwmeester, H. Characterization of Titanium Dioxide Nanoparticles in Food Products: Analytical Methods To Define Nanoparticles. J. Agric. Food Chem. 2014, 62, 6285-6293. [CrossRef] [PubMed]

60. Rompelberg, C.; Heringa, M.B.; van Donkersgoed, G.; Drijvers, J.; Roos, A.; Westenbrink, S.; Peters, R.; van Bemmel, G.; Brand, W.; Oomen, A.G. Oral intake of added titanium dioxide and its nanofraction from food products, food supplements and toothpaste by the Dutch population. Nanotoxicology 2016, 10, 1404-1414. [CrossRef] [PubMed]

61. Paul, R.; Bautista, L.; de la Varga, M.; Botet, J.M.; Casals, E.; Puntes, V.; Marsal, F. Nano-cotton Fabrics with High Ultraviolet Protection. Text. Res. J. 2010, 80, 454-462. [CrossRef]

62. Hincapié, I.; Caballero-Guzman, A.; Hiltbrunner, D.; Nowack, B. Use of engineered nanomaterials in the construction industry with specific emphasis on paints and their flows in construction and demolition waste in Switzerland. Waste Manag. 2015, 43, 398-406. [CrossRef] [PubMed]

63. Hischier, R.; Nowack, B.; Gottschalk, F.; Hincapie, I.; Steinfeldt, M.; Som, C. Life cycle assessment of façade coating systems containing manufactured nanomaterials. J. Nanopart. Res. 2015, 17, 68. [CrossRef]

64. Zhang, Y.; Li, S.; Huang, F.; Wang, F.; Duan, W.; Li, J.; Shen, Y.; Xie, A. Functionalization of cotton fabrics with rutile TiO 2 nanoparticles: Applications for superhydrophobic, UV-shielding and self-cleaning properties. Russ. J. Phys. Chem. A 2012, 86, 413-417. [CrossRef]

65. Shah, S.N.A.; Shah, Z.; Hussain, M.; Khan, M. Hazardous Effects of Titanium Dioxide Nanoparticles in Ecosystem. Bioinorg. Chem. Appl. 2017, 2017, 4101735. [CrossRef] [PubMed]

66. Wong, A.; Daoud, W.A.; Liang, H.H.; Szeto, Y.S. Application of rutile and anatase onto cotton fabric and their effect on the NIR reflection/surface temperature of the fabric. Sol. Energy Mater. Sol. Cells 2015, 134, 425-437. [CrossRef]

67. Iswarya, V.; Palanivel, A.; Chandrasekaran, N.; Mukherjee, A. Toxic effect of different types of titanium dioxide nanoparticles on Ceriodaphnia dubia in a freshwater system. Environ. Sci. Pollut. Res. 2019, 26, 11998-12013. [CrossRef] [PubMed]

68. Hanaor, D.A.H.; Sorrell, C.C. Review of the anatase to rutile phase transformation. J. Mater. Sci. 2011, 46, 855-874. [CrossRef]

69. Lu, P.J.; Huang, S.C.; Chen, Y.P.; Chiueh, L.C.; Shih, D.Y.C. Analysis of titanium dioxide and zinc oxide nanoparticles in cosmetics. J. Food Drug Anal. 2015, 23, 587-594. [CrossRef]

70. Botta, C.; Labille, J.; Auffan, M.; Borschneck, D.; Miche, H.H.; Cabié, M.; Masion, A.; Rose, J.; Bottero, J.-Y.Y. TiÖ-based nanoparticles released in water from commercialized sunscreens in a life-cycle perspective: Structures and quantities. Environ. Pollut. 2011, 159, 1543-1550. [CrossRef] [PubMed]

71. Smijs, T.G.; Pavel, S. Titanium dioxide and zinc oxide nanoparticles in sunscreens: Focus on their safety and effectiveness. Nanotechnol. Sci. Appl. 2011, 4, 95-112. [CrossRef] [PubMed]

72. Bairi, V.G.; Lim, J.-H.; Fong, A.; Linder, S.W. Size characterization of metal oxide nanoparticles in commercial sunscreen products. J. Nanopart. Res. 2017, 19, 256. [CrossRef]

73. Shandilya, N.; Capron, I. Safer-by-design hybrid nanostructures: An alternative to conventional titanium dioxide UV filters in skin care products. RSC Adv. 2017, 7, 20430-20439. [CrossRef]

74. Azimzada, A.; Farner, J.M.; Hadioui, M.; Liu-Kang, C.; Jreije, I.; Tufenkji, N.; Wilkinson, K.J. Release of TiO ${ }_{2}$ nanoparticles from painted surfaces in cold climates: Characterization using a high sensitivity single-particle ICP-MS. Environ. Sci. Nano 2020, 7, 139-148. [CrossRef]

75. Virkutyte, J.; Al-Abed, S.R. Statistical evaluation of potential damage to the $\mathrm{Al}(\mathrm{OH})_{3}$ layer on $\mathrm{nTiO}_{2}$ particles in the presence of swimming pool and seawater. J. Nanopart. Res. 2012, 14, 787. [CrossRef] 
76. Jeon, S.-K.; Kim, E.-J.; Lee, J.; Lee, S. Potential risks of $\mathrm{TiO}_{2}$ and $\mathrm{ZnO}$ nanoparticles released from sunscreens into outdoor swimming pools. J. Hazard. Mater. 2016, 317, 312-318. [CrossRef] [PubMed]

77. Baek, S.; Joo, S.H.; Blackwelder, P.; Toborek, M. Effects of coating materials on antibacterial properties of industrial and sunscreenderived titanium-dioxide nanoparticles on Escherichia coli. Chemosphere 2018, 208, 196-206. [CrossRef] [PubMed]

78. Hanigan, D.; Truong, L.; Schoepf, J.; Nosaka, T.; Mulchandani, A.; Tanguay, R.L.; Westerhoff, P. Trade-offs in ecosystem impacts from nanomaterial versus organic chemical ultraviolet filters in sunscreens. Water Res. 2018, 139, 281-290. [CrossRef]

79. Lorenz, C.; Tiede, K.; Tear, S.; Boxall, A.; Von Goetz, N.; Hungerbühler, K. Imaging and characterization of engineered nanoparticles in sunscreens by electron microscopy, under wet and dry conditions. Int. J. Occup. Environ. Health 2010, 16, 406-428. [CrossRef] [PubMed]

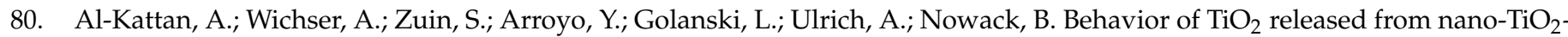
containing paint and comparison to pristine nano-TiO 2 . Environ. Sci. Technol. 2014, 48, 6710-6718. [CrossRef]

81. Rand, L.N.; Bi, Y.; Poustie, A.; Bednar, A.J.; Hanigan, D.J.; Westerhoff, P.; Ranville, J.F. Quantifying temporal and geographic variation in sunscreen and mineralogic titanium-containing nanoparticles in three recreational rivers. Sci. Total Environ. 2020, 743, 140845. [CrossRef] [PubMed]

82. Dedman, C.J.; King, A.; Christie-Oleza, J.; Davies, G.-L. Environmentally relevant concentrations of titanium dioxide nanoparticles pose negligible risk to marine microbes. Environ. Sci. Nano 2021, 8, 1236-1255. [CrossRef] [PubMed]

83. Mackevica, A.; Olsson, M.E.; Hansen, S.F. Quantitative characterization of $\mathrm{TiO}_{2}$ nanoparticle release from textiles by conventional and single particle ICP-MS. J. Nanopart. Res. 2018, 20, 6. [CrossRef]

84. Gottschalk, F.; Nowack, B. The release of engineered nanomaterials to the environment. J. Environ. Monit. 2011, 13, 1145-1155. [CrossRef] [PubMed]

85. Bottero, J.Y.; Rose, J.; De Garidel, C.; Masion, A.; Deutsch, T.; Brochard, G.; Carrière, M.; Gontard, N.; Wortham, H.; Rabilloud, T.; et al. SERENADE: Safer and ecodesign research and education applied to nanomaterial development, the new generation of materials safer by design. Environ. Sci. Nano 2017, 4, 526-538. [CrossRef]

86. Truffier-Boutry, D.; Fiorentino, B.; Bartolomei, V.; Soulas, R.; Sicardy, O.; Benayad, A.; Damlencourt, J.F.; Pépin-Donat, B.; Lombard, C.; Gandolfo, A.; et al. Characterization of photocatalytic paints: A relationship between the photocatalytic propertiesrelease of nanoparticles and volatile organic compounds. Environ. Sci. Nano 2017, 4, 1998-2009. [CrossRef]

87. Azimzada, A.; Farner, J.M.; Jreije, I.; Hadioui, M.; Liu-Kang, C.; Tufenkji, N.; Shaw, P.; Wilkinson, K.J. Single- and Multi-Element Quantification and Characterization of $\mathrm{TiO}_{2}$ Nanoparticles Released From Outdoor Stains and Paints. Front. Environ. Sci. $2020,8,91$. [CrossRef]

88. Philippe, A.; Košík, J.; Welle, A.; Guigner, J.M.; Clemens, O.; Schaumann, G.E. Extraction and characterization methods for titanium dioxide nanoparticles from commercialized sunscreens. Environ. Sci. Nano 2018, 5, 191-202. [CrossRef]

89. Rodríguez-Romero, A.; Ruiz-Gutiérrez, G.; Viguri, J.R.; Tovar-Sánchez, A. Sunscreens as a New Source of Metals and Nutrients to Coastal Waters. Environ. Sci. Technol. 2019, 53, 10177-10187. [CrossRef] [PubMed]

90. Slomberg, D.L.; Catalano, R.; Ziarelli, F.; Viel, S.; Bartolomei, V.; Labille, J.; Masion, A. Aqueous aging of a silica coated TiO 2 UV filter used in sunscreens: Investigations at the molecular scale with dynamic nuclear polarization NMR. RSC Adv. 2020, 10, 8266-8274. [CrossRef]

91. Auffan, M.; Pedeutour, M.; Rose, J.; Masion, A.; Ziarelli, F.; Borschneck, D.; Chaneac, C.; Botta, C.; Chaurand, P.; Labille, J.; et al. Structural degradation at the surface of $\mathrm{T} \mathrm{TiO}_{2}$-based nanomaterial used in cosmetics. Environ. Sci. Technol. 2010, 44, 2689-2694. [CrossRef]

92. Sotiriou, G.A.; Watson, C.; Murdaugh, K.M.; Darrah, T.H.; Pyrgiotakis, G.; Elder, A.; Brain, J.D.; Demokritou, P. Engineering safer-by-design silica-coated ZnO nanorods with reduced DNA damage potential. Environ. Sci. Nano 2014, 1, 144-153. [CrossRef] [PubMed]

93. Semenzin, E.; Subramanian, V.; Pizzol, L.; Zabeo, A.; Fransman, W.; Oksel, C.; Hristozov, D.; Marcomini, A. Controlling the risks of nano-enabled products through the life cycle: The case of nano copper oxide paint for wood protection and nano-pigments used in the automotive industry. Environ. Int. 2019, 131, 104901. [CrossRef] [PubMed]

94. Wu, F.; Harper, B.J.; Harper, S.L. Comparative dissolution, uptake, and toxicity of zinc oxide particles in individual aquatic species and mixed populations. Environ. Toxicol. Chem. 2019, 38, 591-602. [CrossRef] [PubMed]

95. Djurišić, A.B.; Chen, X.; Leung, Y.H.; Man Ching Ng, A. ZnO nanostructures: Growth, properties and applications. J. Mater. Chem. 2012, 22, 6526-6535. [CrossRef]

96. Osmond, M.J.; Mccall, M.J. Zinc oxide nanoparticles in modern sunscreens: An analysis of potential exposure and hazard. Nanotoxicology 2010, 4, 15-41. [CrossRef]

97. Jiang, J.; Pi, J.; Cai, J. The Advancing of Zinc Oxide Nanoparticles for Biomedical Applications. Bioinorg. Chem. Appl. 2018, 2018 , 18. [CrossRef] [PubMed]

98. Mirzaei, H.; Darroudi, M. Zinc oxide nanoparticles: Biological synthesis and biomedical applications. Ceram. Int. 2017, 43, 907-914. [CrossRef]

99. Lewicka, Z.A.; Benedetto, A.F.; Benoit, D.N.; Yu, W.W.; Fortner, J.D.; Colvin, V.L. The structure, composition, and dimensions of $\mathrm{TiO}_{2}$ and $\mathrm{ZnO}$ nanomaterials in commercial sunscreens. J. Nanopart. Res. 2011, 13, 3607-3617. [CrossRef] 
100. Wong, S.W.Y.; Zhou, G.J.; Leung, P.T.Y.; Han, J.; Lee, J.S.; Kwok, K.W.H.; Leung, K.M.Y. Sunscreens containing zinc oxide nanoparticles can trigger oxidative stress and toxicity to the marine copepod Tigriopus japonicus. Mar. Pollut. Bull. 2020, 154, 111078. [CrossRef] [PubMed]

101. Windler, L.; Lorenz, C.; Von Goetz, N.; Hungerbühler, K.; Amberg, M.; Heuberger, M.; Nowack, B. Release of titanium dioxide from textiles during washing. Environ. Sci. Technol. 2012, 46, 8181-8188. [CrossRef] [PubMed]

102. Garza-Cervantes, J.A.; Chávez-Reyes, A.; Castillo, E.C.; García-Rivas, G.; Ortega-Rivera, O.A.; Salinas, E.; Ortiz-Martínez, M.; Gómez-Flores, S.L.; Peña-Martínez, J.A.; Pepi-Molina, A.; et al. Synergistic antimicrobial effects of silver/transition-metal combinatorial treatments. Sci. Rep. 2017, 7, 903. [CrossRef] [PubMed]

103. Abou El-Nour, K.M.M.; Eftaiha, A.; Al-Warthan, A.; Ammar, R.A.A. Synthesis and applications of silver nanoparticles. Arab. J. Chem. 2010, 3, 135-140. [CrossRef]

104. Yu, S.J.; Yin, Y.G.; Liu, J.F. Silver nanoparticles in the environment. Environ. Sci. Process. Impacts 2013, 15, 78-92. [CrossRef] [PubMed]

105. Durán, N.; Durán, M.; de Jesus, M.B.; Seabra, A.B.; Fávaro, W.J.; Nakazato, G. Silver nanoparticles: A new view on mechanistic aspects on antimicrobial activity. Nanomed. Nanotechnol. Biol. Med. 2016, 12, 789-799. [CrossRef]

106. Kędziora, A.; Speruda, M.; Krzyżewska, E.; Rybka, J.; Łukowiak, A.; Bugla-Płoskońska, G. Similarities and differences between silver ions and silver in nanoforms as antibacterial agents. Int. J. Mol. Sci. 2018, 19, 444. [CrossRef] [PubMed]

107. El-Kheshen, A.A.; El-Rab, S.F.G. Effect of reducing and protecting agents on size of silver nanoparticles and their anti-bacterial activity. Der Pharma Chem. 2012, 4, 53-65.

108. Pandiarajan, J.; Krishnan, M. Properties, synthesis and toxicity of silver nanoparticles. Environ. Chem. Lett. 2017, 15, 387-397. [CrossRef]

109. Abbasi, E.; Milani, M.; Aval, S.F.; Kouhi, M.; Akbarzadeh, A.; Nasrabadi, H.T.; Nikasa, P.; Joo, S.W.; Hanifehpour, Y.; Nejati-Koshki, K.; et al Silver nanoparticles: Synthesis methods, bio-applications and properties. Crit. Rev. Microbiol. 2016, 42, 173-180. [CrossRef] [PubMed]

110. Kittler, S.; Greulich, C.; Diendorf, J.; Koller, M.; Epple, M. Toxicity of Silver Nanoparticles Increases during Storage Because of Slow Dissolution under Release of Silver Ions. Chem. Mater. 2010, 22, 4548-4554. [CrossRef]

111. Jones, A.M.; Garg, S.; He, D.; Pham, A.N.; Waite, T.D. Superoxide-mediated formation and charging of silver nanoparticles. Environ. Sci. Technol. 2011, 45, 1428-1434. [CrossRef] [PubMed]

112. Ma, R.; Levard, C.; Marinakos, S.M.; Cheng, Y.; Liu, J.; Michel, F.M.; Brown, G.E.; Lowry, G.V. Size-controlled dissolution of organic-coated silver nanoparticles. Environ. Sci. Technol. 2012, 46, 752-759. [CrossRef]

113. Völker, C.; Kämpken, I.; Boedicker, C.; Oehlmann, J.; Oetken, M. Toxicity of silver nanoparticles and ionic silver: Comparison of adverse effects and potential toxicity mechanisms in the freshwater clam Sphaerium corneum. Nanotoxicology 2015, 9, 677-685. [CrossRef] [PubMed]

114. Organisation for Economic Co-Operation and Development. Environment, Health and Safety Publications Series on the Safety of Manufactured Nanomaterials No. 83 Silver Nanoparticles: Summary of the Dossier. Available online: https: / /www.oecd.org/ officialdocuments / publicdisplaydocumentpdf/?cote=env/jm/mono(2017)31\&doclanguage=en (accessed on 26 July 2021).

115. Thwala, M.; Musee, N.; Sikhwivhilu, L.; Wepener, V. The oxidative toxicity of Ag and ZnO nanoparticles towards the aquatic plant Spirodela punctuta and the role of testing media parameters. Environ. Sci. Process. Impacts 2013, 15, 1830-1843. [CrossRef] [PubMed]

116. Thwala, M.; Klaine, S.; Musee, N. Exposure Media and Nanoparticle Size Influence on the Fate, Bioaccumulation, and Toxicity of Silver Nanoparticles to Higher Plant Salvinia minima. Molecules 2021, 26, 2305. [CrossRef] [PubMed]

117. Dallas, P.; Sharma, V.K.; Zboril, R. Silver polymeric nanocomposites as advanced antimicrobial agents: Classification, synthetic paths, applications, and perspectives. Adv. Colloid Interface Sci. 2011, 166, 119-135. [CrossRef] [PubMed]

118. Fabrega, J.; Luoma, S.N.; Tyler, C.R.; Galloway, T.S.; Lead, J.R. Silver nanoparticles: Behaviour and effects in the aquatic environment. Environ. Int. 2011, 37, 517-531. [CrossRef]

119. García-Barrasa, J.; López-De-luzuriaga, J.M.; Monge, M. Silver nanoparticles: Synthesis through chemical methods in solution and biomedical applications. Cent. Eur. J. Chem. 2011, 9, 7-19. [CrossRef]

120. Lorenz, C.; Windler, L.; von Goetz, N.; Lehmann, R.P.P.; Schuppler, M.; Hungerbühler, K.; Heuberger, M.; Nowack, B. Characterization of silver release from commercially available functional (nano)textiles. Chemosphere 2012, 89, 817-824. [CrossRef] [PubMed]

121. Künniger, T.; Gerecke, A.C.; Ulrich, A.; Huch, A.; Vonbank, R.; Heeb, M.; Wichser, A.; Haag, R.; Kunz, P.; Faller, M. Release and environmental impact of silver nanoparticles and conventional organic biocides from coated wooden façades. Environ. Pollut. 2014, 184, 464-471. [CrossRef]

122. Echavarri-Bravo, V.; Paterson, L.; Aspray, T.J.; Porter, J.S.; Winson, M.K.; Hartl, M.G.J. Natural marine bacteria as model organisms for the hazard-assessment of consumer products containing silver nanoparticles. Mar. Environ. Res. 2017, 130, 293-302. [CrossRef] [PubMed]

123. Farkas, J.; Peter, H.; Christian, P.; Gallego Urrea, J.A.; Hassellöv, M.; Tuoriniemi, J.; Gustafsson, S.; Olsson, E.; Hylland, K.; Thomas, K.V. Characterization of the effluent from a nanosilver producing washing machine. Environ. Int. 2011, 37, 1057-1062. [CrossRef] [PubMed] 
124. Reed, R.B.; Zaikova, T.; Barber, A.; Simonich, M.; Lankone, R.; Marco, M.; Hristovski, K.; Herckes, P.; Passantino, L.; Fairbrother, D.H.; et al. Potential Environmental Impacts and Antimicrobial Efficacy of Silver- and Nanosilver-Containing Textiles. Environ. Sci. Technol. 2016, 50, 4018-4026. [CrossRef]

125. Kim, J.B.; Kim, J.Y.; Yoon, T.H. Determination of silver nanoparticle species released from textiles into artificial sweat and laundry wash for a risk assessment. Hum. Ecol. Risk Assess. 2017, 23, 741-750. [CrossRef]

126. Gagnon, V.; Button, M.; Boparai, H.K.; Nearing, M.; O'Carroll, D.M.; Weber, K.P. Influence of realistic wearing on the morphology and release of silver nanomaterials from textiles. Environ. Sci. Nano 2019, 6, 411-424. [CrossRef]

127. Kaegi, R.; Englert, A.; Gondikas, A.; Sinnet, B.; von der Kammer, F.; Burkhardt, M. Release of $\mathrm{TiO}_{2}-(\mathrm{Nano})$ particles from construction and demolition landfills. NanoImpact 2017, 8, 73-79. [CrossRef]

128. Cascio, C.; Geiss, O.; Franchini, F.; Ojea-Jimenez, I.; Rossi, F.; Gilliland, D.; Calzolai, L. Detection, quantification and derivation of number size distribution of silver nanoparticles in antimicrobial consumer products +. J. Anal. At. Spectrom. 2015, 30, 1255-1265. [CrossRef]

129. Aznar, R.; Barahona, F.; Geiss, O.; Ponti, J.; José Luis, T.; Barrero-Moreno, J. Quantification and size characterisation of silver nanoparticles in environmental aqueous samples and consumer products by single particle-ICPMS. Talanta 2017, 175, 200-208. [CrossRef] [PubMed]

130. Potter, P.M.; Navratilova, J.; Rogers, K.R.; Al-Abed, S.R. Transformation of silver nanoparticle consumer products during simulated usage and disposal. Environ. Sci. Nano 2019, 6, 592-598. [CrossRef]

131. Liljenström, C.; Lazarevic, D.; Finnveden, G. Silicon-Based Nanomaterials in a Life-Cycle Perspective, Including a Case Study on Self-Cleaning Coatings; Royal Institute of Technology: Stockholm, Sweden, 2013; ISBN 9789175019420.

132. Michel, K.; Scheel, J.; Karsten, S.; Stelter, N.; Wind, T. Risk assessment of amorphous silicon dioxide nanoparticles in a glass cleaner formulation. Nanotoxicology 2013, 7, 974-988. [CrossRef] [PubMed]

133. Fröhlich, E.; Roblegg, E. Models for oral uptake of nanoparticles in consumer products. Toxicology 2012, 291, 10-17. [CrossRef] [PubMed]

134. Zuin, S.; Massari, A.; Ferrari, A.; Golanski, L. Formulation effects on the release of silica dioxide nanoparticles from paint debris to water. Sci. Total Environ. 2014, 476-477, 298-307. [CrossRef]

135. Lajmanovich, R.C.; Peltzer, P.M.; Martinuzzi, C.S.; Attademo, A.M.; Colussi, C.L.; Bassó, A. Acute Toxicity of Colloidal Silicon Dioxide Nanoparticles on Amphibian Larvae: Emerging Environmental Concern. Int. J. Environ. Res. 2018, 12, 269-278. [CrossRef]

136. Vidya, P.V.; Chitra, K.C. Irreversible Nanotoxicity of Silicon Dioxide Nanoparticles in the Freshwater Fish, Oreochromis mossambicus (Peters 1852). Asian Fish. Sci. 2018, 31, 146-160. [CrossRef]

137. Sahu, D.; Kannan, G.M.; Tailang, M.; Vijayaraghavan, R. In Vitro Cytotoxicity of Nanoparticles: A Comparison between Particle Size and Cell Type. J. Nanosci. 2016, 2016, 4023852. [CrossRef]

138. Lombi, E.; Donner, E.; Scheckel, K.G.; Sekine, R.; Lorenz, C.; Goetz, N.V.; Nowack, B. Silver speciation and release in commercial antimicrobial textiles as influenced by washing. Chemosphere 2014, 111, 352-358. [CrossRef]

139. Batchelor-McAuley, C.; Tschulik, K.; Neumann, C.C.M.; Laborda, E.; Compton, R.G. Why are silver nanoparticles more toxic than bulk silver? Towards understanding the dissolution and toxicity of silver nanoparticles. Int. J. Electrochem. Sci. 2014, 9, 1132-1138.

140. Lehutso, R.F.; Thwala, M. Assessment of Nanopollution in Water Environments from Commercial Products. Nanomaterials 2021, 11, 2537. [CrossRef] [PubMed]

141. Benn, T.; Cavanagh, B.; Hristovski, K.; Posner, J.D.; Westerhoff, P. The Release of Nanosilver from Consumer Products Used in the Home. Physiol. Behav. 2016, 176, 100-106. [CrossRef] [PubMed]

142. Quadros, M.E.; Pierson, R.; Tulve, N.S.; Willis, R.; Rogers, K.; Thomas, T.A.; Marr, L.C. Release of silver from nanotechnologybased consumer products for children. Environ. Sci. Technol. 2013, 47, 8894-8901. [CrossRef] [PubMed]

143. Reed, R.B.; Martin, D.P.; Bednar, A.J.; Montaño, M.D.; Westerhoff, P.; Ranville, J.F. Multi-day diurnal measurements of Ti-containing nanoparticle and organic sunscreen chemical release during recreational use of a natural surface water. Environ. Sci. Nano 2017, 4 , 69-77. [CrossRef]

144. Markus, A.A.; Krystek, P.; Tromp, P.C.; Parsons, J.R.; Roex, E.W.M.; Voogt, P.D.; Laane, R.W.P.M. Determination of metal-based nanoparticles in the river Dommel in The Netherlands via ultrafiltration, HR-ICP-MS and SEM. Sci. Total Environ. 2018, 631-632, 485-495. [CrossRef] [PubMed]

145. Gondikas, A.; Von Der Kammer, F.; Kaegi, R.; Borovinskaya, O.; Neubauer, E.; Navratilova, J.; Praetorius, A.; Cornelis, G.; Hofmann, T. Where is the nano? Analytical approaches for the detection and quantification of $\mathrm{TiO}_{2}$ engineered nanoparticles in surface waters. Environ. Sci. Nano 2018, 5, 313-326. [CrossRef]

146. Labille, J.; Slomberg, D.; Catalano, R.; Robert, S.; Apers-Tremelo, M.L.; Boudenne, J.L.; Manasfi, T.; Radakovitch, O. Assessing UV filter inputs into beach waters during recreational activity: A field study of three French Mediterranean beaches from consumer survey to water analysis. Sci. Total Environ. 2020, 706, 136010. [CrossRef] [PubMed]

147. Gao, J.; Sepúlveda, M.S.; Klinkhamer, C.; Wei, A.; Gao, Y.; Mahapatra, C.T. Nanosilver-coated socks and their toxicity to zebrafish (Danio rerio) embryos. Chemosphere 2015, 119, 948-952. [CrossRef]

148. Fastelli, P.; Renzi, M. Exposure of key marine species to sunscreens: Changing ecotoxicity as a possible indirect effect of global warming. Mar. Pollut. Bull. 2019, 149, 110517. [CrossRef]

149. Kalbassi, M.R.; Salari-joo, H.; Johari, A. Toxicity of Silver Nanoparticles in Aquatic Ecosystems: Salinity As the Main Cause in Reducing Toxicity. Iran. J. Toxicol. 2011, 5, 436-443. 
150. Bicherel, P.; Thomas, P.C. Aquatic Toxicity Calculation of Mixtures: A Chemical Activity Approach Incorporating a Bioavailability Reduction Concept. Environ. Sci. Technol. 2021, 55, 11183-11191. [CrossRef] [PubMed]

151. Hou, J.; Wang, L.; Wang, C.; Zhang, S.; Liu, H.; Li, S.; Wang, X. Toxicity and mechanisms of action of titanium dioxide nanoparticles in living organisms. J. Environ. Sci. 2019, 75, 40-53. [CrossRef] [PubMed]

152. Schiavo, S.; Oliviero, M.; Philippe, A.; Manzo, S. Nanoparticles based sunscreens provoke adverse effects on marine microalgae Dunaliella tertiolecta. Environ. Sci. Nano 2018, 5, 3011-3022. [CrossRef]

153. Mueller, N.C.; Nowack, B. Exposure Modeling of Engineered Nanoparticles in the Environment. EMPA Act. 2008, $42,63$. [CrossRef] [PubMed]

154. Gottschalk, F.; Sonderer, T.; Scholz, R.W.; Nowack, B. Possibilities and limitations of modeling environmental exposure to engineered nanomaterials by probabilistic by probabilistic material flow analysis. Environ. Toxicol. Chem. 2010, 29, 1036-1048. [CrossRef] [PubMed] 